\title{
Conflicts of Authorship and the Autonomization of Cinema in Pre-60s United States and France
}

Qu'est-ce qu'un (auteur de) film? Prétendants au statut d'auteur et autonomisation du cinéma avant les années 1960 (États-Unis-France) Qué es una (un autor de) película? Aspirantes al estatus de autor y autonomización del cine antes de los años 1960 (Estados Unidos- Francia)

\section{Jérôme Pacouret}

Translator. Jean-Yves Bart

\section{OpenEdition}

\section{Journals}

Electronic version

URL: http://journals.openedition.org/bssg/342

DOI: $10.4000 /$ bssg.342

ISSN: 2490-9424

\section{Publisher}

Presses universitaires de Vincennes

\section{Electronic reference}

Jérôme Pacouret, "Conflicts of Authorship and the Autonomization of Cinema in Pre-60s United States and France", Biens Symboliques / Symbolic Goods [Online], 4 | 2019, Online since 27 June 2019, connection on 04 March 2021. URL: http://journals.openedition.org/bssg/342 ; DOI: https://doi.org/ $10.4000 /$ bssg. 342 


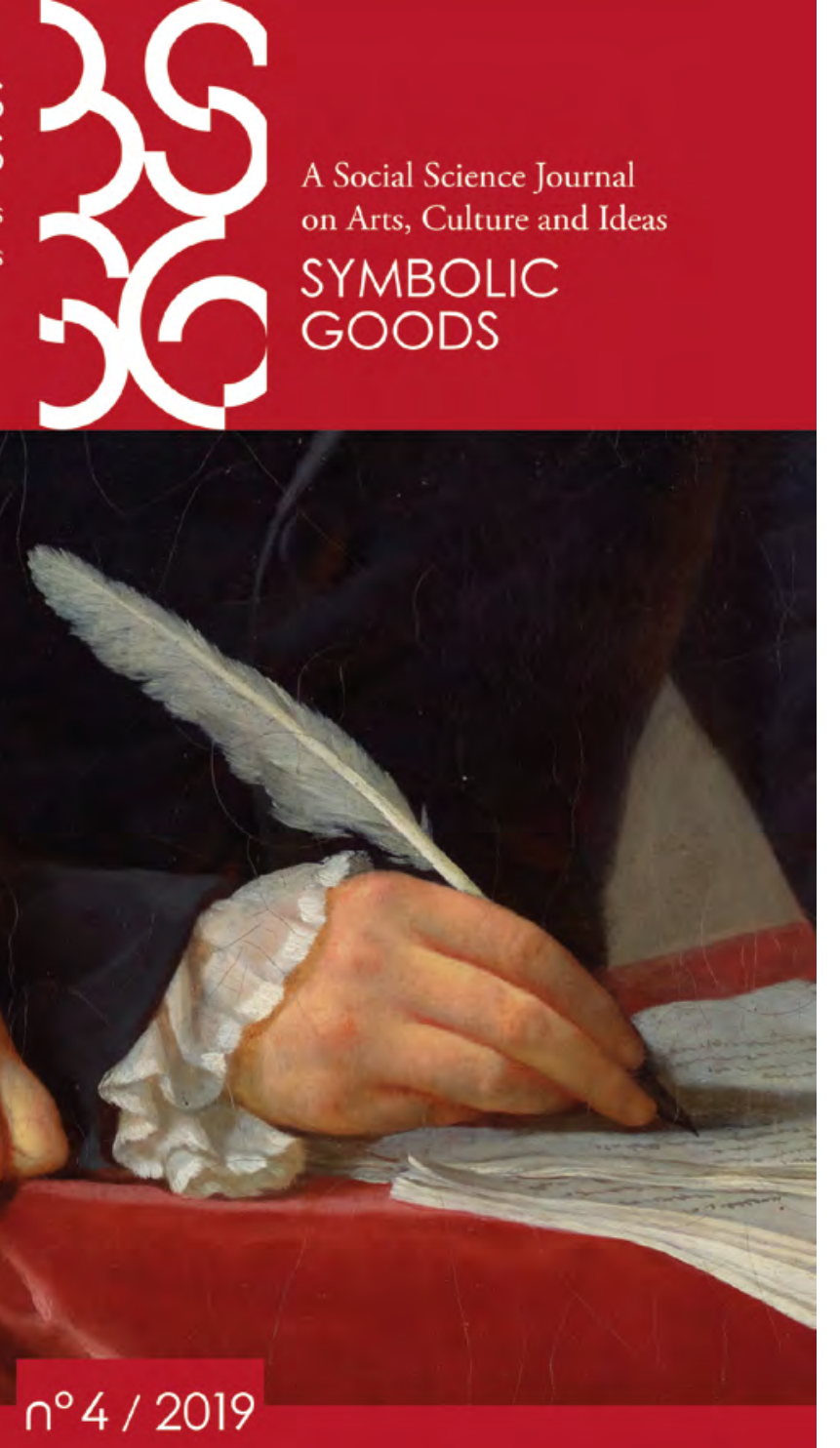

Autonomies des arts et de la culture Autonomies of Art and Culture 


\section{Qu'est-ce qu'un (auteur de) film ? Conflicts of Authorship and the \\ Prétendants au statut d'auteur et autonomisation du cinéma avant les Autonomization of Cinema in Pre-60s United States and France années 1960 (États-Unis-France)}

Jérôme Pacouret

traduction | translation Jean-Yves Bart

\begin{abstract}
Fallait-il que les films de cinéma soient attribués à des auteurs pour que le cinéma devienne un art distinct des autres ? Quels étaient les auteurs de cet art nouveau ? Pierre Bourdieu et Howard Becker ont en commun d'avoir discuté l'attribution des œuvres aux seuls auteurs et artistes. En posant à plusieurs reprises la question «Qui a créé les créateurs ? ", Pierre Bourdieu a contesté " l'idéologie charismatique du créateur " en attribuant la valeur des œuvres aux champs littéraires et artistiques dans leur ensemble (Bourdieu 1977, 1992, 2002, Bourdieu \& Delsaut 1975). Howard Becker a expliqué que les œuvres d'art étaient le produit de coopérations institutionnalisées entre un grand nombre de personnes (un « monde de l'art »). II a distingué les artistes et le «personnel de renfort » composant les mondes de l'art en fonction de particularités de leurs tâches, tout en constatant que la définition des artistes était relative et faisait l'objet de débats comme ceux portant sur la définition des auteurs de cinéma (Becker 1988). "L'idéologie charismatique du créateur »-que Pierre Bourdieu définissait à la fois comme une prénotion et comme une « idéologie bien fondée " (Bourdieu 1977) - n'en demeure pas moins un phénomène structurant la production, la diffusion et la réception des œuvres cinématographiques. On peut aisément
\end{abstract}

Was it necessary for films to be attributed to authors for cinema to become an original art? Who were the authors of this new art? Pierre Bourdieu and Howard Becker both discussed the attribution of literary and artistic works to sole authors and artists. Bourdieu repeatedly asked "Who creates the creator?" (Bourdieu 1977; 1996; 2002; Bourdieu \& Delsaut 1975). He challenged the "charismatic ideology of the creator" by attributing the value of artworks to the literary and artistic fields as a whole. Howard Becker explained that an artwork results from institutionalized cooperation between a large number of individuals (an "art world") (Becker 1988). He introduced a distinction between artists and the "support personnel" of art worlds, which is partly based on their tasks. Howard Becker also observed that the definition of artists was a representation and a debated issue, especially in the case of motion pictures. The "charismatic ideology of the creator"-which Pierre Bourdieu described both as a preconception and a "well-founded" ideology (Bourdieu 1977)-remains a phenomenon that structures the production, dissemination, and reception of cinematographic works. For example, in France, film critics and cinema goers often praise "cinéma d'auteur" as opposed to "commercial" cinema. 
s'en convaincre à la lecture de critiques de films ou en observant qu'en France un " cinéma d'auteur » est régulièrement valorisé par opposition à un " cinéma commercial ». Cet article montre que l'attribution des films à des auteurs a contribué à deux dimensions du processus d'autonomisation du cinéma : la différenciation du cinéma par rapport à d'autres productions culturelles et la définition d'une valeur cinématographique irréductible au succès commercial et à la

popularité des films.

Plusieurs sociologues ont déjà associé l'attribution des films aux réalisateurs à l'autonomisation, l'artification ou la légitimation artistique du cinéma. Philippe Mary a considéré que la politique des auteurs des Cahiers du cinéma et la Nouvelle Vague, en imposant le pouvoir des réalisateurs sur leurs collaborateurs, avaient permis l'autonomisation du cinéma et son assimilation à un art (Mary 2006). Selon Martine Chaudron et Nathalie Heinich, les critiques des Cahiers du cinéma et cinéastes de la Nouvelle Vague ont inventé la qualité d'auteur des réalisateurs et promu le cinéma au rang d'art en valorisant des films de séries $B$ en tant qu'expression du génie de réalisateurs peu conventionnels et en mettant en avant le rôle créatif des réalisateurs par rapport aux contributions des producteurs et des acteurs (Chaudron \& Heinich 2012). Selon les deux chercheuses, « il ne peut y avoir véritablement "auteur" du film - celui qui appose mais aussi qui impose sa signature - que dans la mesure où le réalisateur, ou metteur en scène, maîtrise l'ensemble du processus de production, depuis le choix, voire l'écriture du scénario, jusqu'à l'ultime version du montage » (Chaudron \& Heinich 2012 : 229-230). À propos du cas états-unien, Shyon Baumann a expliqué que la légitimation artistique du cinéma dans les années 1960 avait été favorisée par l'autopromotion des réalisateurs et l'indépendance accrue de ces derniers, qui contrastait avec le manque de reconnaissance et l'assimilation à des techniciens des réalisateurs des décennies précédentes (Baumann 2007). Le travail de Julien Duval contraste
This article shows that the attribution of motion pictures to authors contributed to two dimensions of the autonomization of cinema: the differentiation of cinema from other cultural productions and the definition of a cinematographic value that cannot be reduced to the profitability and box-office success of films.

Several sociologists have already associated the attribution of films to directors with the autonomization, "artification," or artistic legitimation of cinema. Philippe Mary considered that the Cahiers du cinéma's "auteur theory" and the French Nouvelle Vague established cinema as an autonomous art by asserting the power of directors over their collaborators (Mary 2006). According to Martine Chaudron and Nathalie Heinich, Cahiers du cinéma critics and Nouvelle Vague filmmakers invented the authorship of directors and defined cinema as an art (Chaudron \& Heinich 2012). They supposedly did so by heralding $B$ movies as expressions of genius by unconventional directors, and by highlighting the creative role of directors rather than the contributions of producers and actors. Martine Chaudron and Nathalie Heinich argued that "there can only truly be an 'author' of a film - someone who puts a signature on it-insofar as the filmmaker, or director, has control over the entire production process, from the choice or even the writing of the script to the final version of the editing" (Chaudron \& Heinich 2012: 229230). Shyon Baumann explained that the artistic legitimation of Hollywood cinema in the 1960s was favoured by the self-promotion and increased independence of directors, contrasting with their lack of recognition and perception as technicians in previous decades (Baumann 2007). Julien Duval's work stands out by dating the beginning of the autonomization process of cinema back to the 1920s (Duval 2016: 81-128). He argued that the aesthetic 
avec les précédents en faisant débuter le processus d'autonomisation du cinéma dans les années 1920 (Duval 2016 : 81-128). Ce dernier a attribué aux innovations esthétiques de certains metteurs en scène états-uniens et européens le fait que le cinéma se soit affranchi de la tutelle des autres arts et la différenciation de la valeur esthétique des

films par rapport à leur succès auprès du « grand public ».

Ces travaux ont raison d'associer l'attribution des films à des auteurs, sa définition comme un art distinct des autres et la différenciation de la valeur esthétique de films par rapport à leur succès public. Ils présentent cependant plusieurs limites. Premièrement, la périodisation adoptée par Julien Duval est plus satisfaisante que celles des autres recherches citées. C'est entre les années 1890 et les années 1920 que se sont réalisées les trois conditions de l'émergence d'un champ de production culturelle selon Pierre Bourdieu (Bourdieu 1971, Sapiro 2017) : le développement d'un marché, la spécialisation de professionnels et la constitution d'instances de consécration spécifiques (les critiques de cinéma). Deuxièmement, les recherches citées laissent de côté le fait que le statut d'auteur de film revendiqué par les réalisateurs leur a été disputé par d'autres groupes professionnels, et tout particulièrement par les producteurs et les auteurs de scénarios, de livres et de pièces adaptées sous forme de films. Troisièmement, lorsqu'ils considèrent que l'assimilation du cinéma à un art a été contrariée par son caractère " commercial » ou « populaire », les travaux de Julien Duval, Martine Chaudron et Nathalie Heinich ignorent qu'une fraction des prétendants au statut d'auteur de film et des critiques de cinéma ont défini le cinéma comme un art sans souscrire à la logique de «l'économie inversée » objectivée par Pierre Bourdieu dans ses travaux sur le champ littéraire (Bourdieu 1992).

Cet article examine comment plusieurs groupes professionnels ont revendiqué le statut d'auteur de film au nom de différentes conceptions innovations of a few American and European directors enabled cinema to free itself from the tutelage of the other arts and helped motion pictures to be granted aesthetic value regardless of their box-office success.

These studies are right to relate film authorship to the definition of cinema as an original art, and with the emergence of an aesthetic value of motion pictures, distinct from box-office success. However, they have several limitations. First, the periodization adopted by Julien Duval is more accurate than that of the other cited studies. Indeed, it is between the 1890s and the 1920s that the three conditions for the emergence of a field of cultural production according to Bourdieu (Bourdieu 1971; Sapiro 2017) were met: the development of a market, the specialization of a workforce, and the introduction of specific instances of consecration (film critics). Second, these studies neglect the fact that the authorship claims of directors were challenged by other professional groups-mostly producers and the writers of screenplays, books and plays adapted as films. Third, when they argue that the definition of cinema as art was hindered by its "commercial" or "popular" character, the works of Julien Duval, Martine Chaudron, and Nathalie Heinich fail to consider that a fraction of professionals claiming to be authors, as well as some film critics, viewed cinema as a "popular" or "democratic" art. These professionals and critics did not subscribe to the idea of the "reversed economy" put forth by Bourdieu in his research on the literary field (Bourdieu 1996).

This article examines how members and representatives of several occupations claimed authorship of motion pictures. They did so by 
des relations entre le cinéma et d'autres productions culturelles, ainsi qu'en distinguant (ou non) la valeur esthétique des films de leur popularité et de leur rentabilité. En analysant la contribution des luttes de définition des auteurs de films au processus d'autonomisation du cinéma, il vise aussi à mieux comprendre le phénomène d'attribution des œuvres, dont on verra qu'il a été structuré par les relations entre le champ cinématographique et d'autres domaines d'activité.

L'analyse montre que des définitions similaires de l'auteur de film ont été défendues en France et aux États-Unis, malgré les différences entre les modes de production des films observables dans ces deux pays ${ }^{1}$. Ce cadre binational n'a pas pour finalité principale d'observer des points communs ou des différences entre des cas français et états-uniens, mais d'éviter deux formes de " nationalismeméthodologique » (Dumitru 2014, Wimmer \& Schiller 2002) : circonscrire l'analyse aux frontières des États-nations et caractériser a priori un groupe social par sa nationalité ou sa localisation, en supposant que ces propriétés le distinguent de groupes d'autres nationalités. Plutôt que de considérer les professionnels français

1. Entretenue par des concurrences économiques et symboliques internationales, l'idée que les modes de production cinématographique français et états-uniens sont (très) différents occulte de nombreux points communs entre les divisions du travail observables dans ces deux pays (notamment en matière de définition et de hiérarchisation des métiers), la variété de leurs productions, ainsi que les concurrences et les échanges transnationaux de films, d'idées, de techniques et de professionnels qui ont contribué à leur genèse et à leur existence. Les groupes professionnels qui ont revendiqué le statut d'auteur occupaient, avec les acteurs et actrices de premiers rôles, les positions dominantes des hiérarchies professionnelles du cinéma, que ce soit en termes de rémunération, de prestige de leurs activités et de pouvoir sur le reste du personnel. Cela est vrai aux États-Unis comme en France. Pour une vision précise de la division du travail cinématographique française et étatsunienne de la première moitié du siècle, voir les travaux de Janet Staiger (Bordwell, Staiger, Thompson 1985) et de Colin Crisp (1987) promoting different conceptions of the relations between cinema and other cultural productions, and by distinguishing (or not) the aesthetic value of films from their popularity and profitability. This article, which studies how authorship conflicts contributed to the autonomization of cinema, also aims to reach a better understanding of the attribution of motion pictures. It shows that film authorship was shaped by the relations between the field of cinema and other fields.

This article reveals that similar conceptions of film authorship were promoted in France and in the US, despite differences in film production between the two countries ${ }^{1}$. The main purpose of this binational framework is not to observe similarities or differences between two national cases, but to avoid two forms of "methodological nationalism" (Dumitru 2014; Wimmer \& Schiller 2002)-circumscribing the study to the borders of nation-states and characterizing a social group based on nationality or location, assuming that these properties distinguish it from groups of other nationalities. Instead of considering that French and American professionals belong to national fields or worlds, I study them as actors in a transnational division of cinematographic labour, as well

1. The idea that French and American modes of film production are (very) different has been nurtured by international economic and symbolic competitions. This idea overshadows many similarities between the divisions of labour that can be observed in the two countries (such as the definition and stratification of occupations), the variety of their productions, as well as the transnational competitions and exchanges of films, ideas, techniques, and professionals that contributed to the genesis and existence of French and American cinema. In both countries, the occupations whose members and representatives claimed authorship held dominant positions in the professional hierarchies of cinema, alongside lead actors in terms of salary, prestige, and power over the rest of the personnel alike. For more information on the division of film labour in France and the US in the first half of the twentieth century, see Janet Staiger (Bordwell, Staiger, Thompson 1985) and Colin Crisp (1987). 
et états-uniens comme appartenant à des champs ou monde cinématographiques nationaux, on les étudie ici en tant qu'acteurs d'une division transnationale du travail cinématographique, de luttes de définitions des auteurs de films et d'un processus d'autonomisation opérant dans différents pays. Cette démarche de dénationalisation relative de l'objet d'étude se justifie d'autant plus que le cinéma se caractérise, depuis son origine, par des échanges transnationaux et des concurrences internationales très intenses. Ces échanges et concurrences ont contribué au processus d'autonomisation du cinéma (Duval 2016 : 124-126) et d'appropriation des films par des auteurs. Sans analyser toutes les dimensions internationales et transnationales de ces phénomènes, on prendra en compte les revendications d'organisations internationales de prétendants au statut d'auteur et les échanges qui ont structuré les rapports des professionnels à la réussite commerciale des films.

Les prises de position étudiées sont celles de scénaristes, de producteurs et de réalisateurs qui sont intervenus dans les luttes de définition de l'auteur de film, dans la presse ou dans le cadre de négociations autour du droit de propriété cinématographique. À défaut de pouvoir rendre compte des discours de tous les acteurs intervenant dans les luttes de définition de l'auteur de film, on a privilégié les prises de position de dirigeants d'organisations professionnelles et de professionnels ayant rencontré du succès auprès des critiques et/ou des spectateurs - ce qui faisait de leurs discours les plus susceptibles d'être partagés par d'autres membres de leurs groupes ou de servir de modèles à ces derniers. Leurs prises de position ne sont pas pour autant représentatives de toutes les conceptions de la division du travail cinématographique défendues par les scénaristes, les producteurs et les réalisateurs ${ }^{2}$. La période étudiée commence

2. Par exemple, tous les réalisateurs hollywoodiens ne considéraient pas les films comme des œuvres individuelles et des scénaristes et réalisateurs des deux pays se sont accordés pour considérer qu'un film était l'œuvre conjointe du réalisateur et du scénariste. as in authorship conflicts and a process of autonomization unfolding in several countries. This partial denationalization of the study is all the more relevant as cinema has been characterized by very intense transnational exchanges and international competitions since its inception. These exchanges and competitions contributed to its process of autonomization (Duval 2016: 124-126) and to the appropriation of films by authors. Although I cannot present all the international and transnational dimensions of these phenomena here, I will consider the claims of international professional associations and the exchanges that structured the attitudes of screenwriters, producers, and directors towards box-office success.

My sources include the discourses of screenwriters, producers, and directors who participated in authorship conflicts in the press and in copyright negotiations. Being unable to account for all the existing views on filmmaking, I have focused on spokespersons of professional associations and commercially successful or critically acclaimed professionals. The fame and recognition of these professionals made their views more likely to be shared by other members of their groups or to serve as models. However, their discourses, are not representative of all the views on filmmaking expressed by screenwriters, producers, and directors ${ }^{2}$. The period under study begins with the emergence of film authorship battles in the 1910 s and ends in the late 1950s/early 1960s, when the status

2. For instance, not all Hollywood directors defined themselves as the sole authors of motion pictures. Likewise, some scriptwriters and directors in both countries agreed to define a film as the joint work of the director and the scriptwriter. 
avec l'émergence des luttes de définition de l'auteur de film (dans les années 1910) et s'étend jusqu'à la fin des années 1950 et au début des années 1960, lors desquelles se sont achevées les négociations des définitions des auteurs de film codifiées par la loi du 11 mars 1957 sur le droit d'auteur et le Copyright Act de 1976. Cette périodisation permet d'analyser les luttes de définition des auteurs avant que la Nouvelle Vague, le New American Cinema et le Nouvel Hollywood, déjà bien étudiés, ne confortent la reconnaissance des réalisateurs comme auteurs. Cet article est fondé sur une thèse consacrée aux luttes de définition des auteurs de films et de leurs droits de propriété des années 1900 aux années 2010 (Pacouret 2018). On a fait le choix de ne pas féminiser l'écriture de ce texte en raison de l'exclusion presque complète des femmes des métiers de prétendants au statut d'auteur pendant la période étudiée. Les relations entre ce phénomène et les luttes de définition de l'auteur seront l'objet d'une autre publication.

La première section présente brièvement les enjeux et les acteurs des luttes de définition de l'auteur de film. Les sections suivantes portent respectivement sur la différenciation du cinéma par rapport à d'autres productions littéraires et artistiques et sur la différenciation de la valeur esthétique et commerciale des œuvres cinématographiques.

\section{Les luttes de définition des auteurs de cinéma}

Les luttes de définition des auteurs de films ont contribué au processus d'autonomisation du cinéma sans pour autant être réductibles à un déterminant, un effet ou un simple corollaire de ce processus. Ces luttes avaient pour enjeu non seulement la définition du cinéma et de ses relations avec d'autres productions culturelles, mais aussi la répartition du pouvoir, de l'argent et de la reconnaissance entre le personnel cinématographique. of author was codified by the 1957 French copyright law and the 1976 Copyright Act in the US. This periodization shows that film authorship existed and was disputed long before the Nouvelle Vague, New American Cinema, and New Hollywood-which have already been studied extensively-reinforced the recognition of directors as authors. This article is based on a PhD thesis on film authorship and copyright law from the 1900s to the 2010s (Pacouret 2018).

The first section briefly introduces the participants in authorship battles and their motives. Subsequent sections respectively address the differentiation of cinema from other cultural productions and the differentiation of the aesthetic and economic value of motion pictures.

\section{Film Authorship Conflicts}

Struggles over the definition of film authors have contributed to the process of autonomization of cinema. However, these conflicts cannot be reduced to a cause, an effect or a mere corollary of the differentiation of cinema. What was at stake in these struggles was not only the definition of cinema and its relations with other cultural productions, but also the distribution of power, money, and recognition among film occupations. 
Le statut d'auteur de film a été revendiqué par des groupes professionnels qui se sont différenciés dans les années 1900 et 1910, en relation avec des transformations de la production cinématographique comme l'allongement du temps des métrages et la hausse de la production et de la taille des entreprises (Bordwell, Staiger, Thompson 1985 : 113-153, Carou 2011). À partir de 1907, la coordination et la direction des tournages, auparavant assurées par les cameramen, ont été opérées par des metteurs en scène, sur le modèle du théâtre. Entre la fin des années 1900 et le début des années 1910, l'écriture des histoires, dont étaient jusque-là en charge les cameramen et les metteurs en scène, a été confiée à des auteurs pour permettre l'allongement du temps des métrages et pour tirer profit de la notoriété d'écrivains et de dramaturges. Le poste de producteur s'est différencié dans les plus grandes entreprises à partir des années 1910. Par la suite, le terme de producteur a désigné à la fois les patrons des entreprises de fabrication des films et ceux qui dirigeaient les tâches de planification des tournages et de contrôle des coûts.

Les metteurs en scène, les producteurs ainsi que les auteurs de scénarios, de livres et de pièces adaptées au cinéma ont revendiqué le statut d'auteur de film à différentes fins et dans différents cadres. Michel Foucault a mis en relation l'émergence de la « fonction auteur » en littérature avec le développement de la propriété des écrits (Foucault 2001). Les prétendants au statut d'auteur de cinéma ont cherché à obtenir des droits analogues à ceux qu'accordait aux écrivains et aux artistes le droit français, états-uniens et international de la propriété littéraire et artistique. Les films ont été définis comme des œuvres protégées par le droit d'auteur et le copyright par une révision de la convention de Berne de 1908 et par un amendement à la législation états-unienne datée de 1912. Ces législations font suite à deux ensembles de luttes (Carou 2002, Decherney 2012, Jeancolas, Meusy, Pinel 1996). D'une part, des entreprises
Film authorship was claimed by members and spokespersons of occupations that specialized in the 1900s and 1910s, in connection with transformations such as the production of longer movies and the growth of motion picture companies (Bordwell, Staiger, Thompson 1985: 113-153; Carou 2011). From 1907 on, the coordination and direction of shootings, previously taken on by cameramen, was appropriated by directors following the model of theatre. Between the late 1900 s and early 1910 s, the writing of stories, previously assumed by cameramen and directors, was entrusted to writers. This facilitated the production of feature films and also aimed to benefit from the popularity of writers and playwrights. In the 1910 s, the position of producer began to differentiate in the largest companies. Subsequently, the term "producer" came to refer to both the companies' owners and those in charge of planning production and controlling costs.

Directors, producers, and the authors of scripts, books, and plays adapted for the screen claimed to be authors for various purposes and in various settings. Michel Foucault related the emergence of the "author function" in literature with the development of property over writing (Foucault 2001). Self-proclaimed film authors sought to secure rights similar to those granted to writers and artists under the French, US, and international laws on literary and artistic property. Films were defined as copyrighted works by a revision of the 1908 Berne Convention and a 1912 amendment to US law. These legal provisions followed two sets of struggles (Carou 2002; Decherney 2012; Jeancolas, Meusy, Pinel 1996). On the one hand, film companies tried to prevent their competitors from reproducing and selling the films they had produced. On the other, writers, playwrights, publishers, and theatre owners sought to control film 
cinématographiques ont cherché à empêcher leurs concurrentes de commercialiser les films qu'elles avaient produites. D'autre part, des écrivains, des dramaturges, des éditeurs et des directeurs de théâtre se sont efforcés de contrôler les adaptations cinématographiques de livres et de pièces, pour en tirer profit et pour limiter la concurrence du cinéma sur le théâtre.

Des années 1920 aux années 1950, à l'occasion de nombreuses révisions ou tentatives de réécriture du droit français, états-unien et international de la propriété littéraire et artistique ${ }^{3}$, des écrivains, scénaristes, producteurs et metteurs en scène ont revendiqué le statut de seul auteur et propriétaire des films. Ils ont été représentés par des organisations préexistantes, comme des sociétés d'auteurs fondées par des dramaturges et des écrivains (la Société des auteurs et compositeurs dramatiques et l'Authors League), des syndicats patronaux des entreprises cinématographiques et/ou par de nouvelles organisations professionnelles créées pour défendre le statut d'auteur et de propriétaire de leurs membres, comme la Société des auteurs de films et la Screen Writers Guild, respectivement créées en 1917 et en 1920 (Armengol 2013, Carou 2002, Jeancolas et al. 1996, Loyant 2009, Wheaton 1974). Au cours des années 1930 et 1940 , pour mieux intervenir dans des négociations autour des normes nationales et internationales de la propriété des films, les prétendants au statut d'auteur ont constitué des organisations

3. Sans cesse renégociée pendant la première moitié $\mathrm{du} x \mathrm{x}^{\mathrm{e}}$ siècle, la Convention de Berne a été révisée en 1928 et en 1948. Au milieu des années 1930, un projet de loi sur la propriété littéraire et artistique, associé au nom de Jean Zay, a été négocié puis abandonné lors la Seconde Guerre mondiale. Les négociations se sont poursuivies sous l'Occupation, à la Libération et aboutirent à la loi du 11 mars 1957. Aux États-Unis, dans les années 1920 et 1930, de nombreux projets de lois ont été élaborés, sans succès, afin de permettre la ratification de la convention de Berne. Un vaste projet de réécriture de la législation sur le copyright a été négocié à partir des années 1950 et a abouti au Copyright Act de 1976. adaptations of books and plays, benefit from adaptations, and protect theatre from the competition of cinema.

From the 1920 s to the 1950 s, writers, screenwriters, producers, and directors participated in numerous revisions or attempts to revise French, US, and international copyright laws ${ }^{3}$. In these negotiations, they claimed the status of sole author and owner of films. They were represented by preexisting organizations, such as societies of authors founded by playwrights and writers (the Sociéte des auteurs et compositeurs dramatiques and the Authors League), associations of motion picture employers and/or new professional associations created to defend their members' authorship and property rights, such as the Société des auteurs de films (1917) and the Screen Writers Guild (1920) (Armengol 2013; Carou 2002; Jeancolas et al. 1996; Loyant 2009; Wheaton 1974). During the 1930 s and 1940s, in order to take part in national and international copyright negotiations, producers, screenwriters, and directors founded international associations bringing together professionals from a few dozen countries: the International Federation of Film

3. The Berne Convention was constantly renegotiated during the first half of the twentieth century, and revised in 1928 and 1948. In the mid-1930s, a bill on literary and artistic property, named after Jean Zay, was drafted, debated and then abandoned during the Second World War Negotiations continued during the German occupation, after the French Liberation, leading up to the 11 March 1957 law. In the 1920s and 1930s, numerous bills were unsuccessfully drafted in order for the US to ratify the Berne Convention. Negotiations began in the 1950s over a comprehensive revision of copyright law, leading to the 1976 Copyright Act. 
internationales qui regroupaient des professionnels de quelques dizaines de pays : la Fédération internationale des associations de producteurs de films et la Fédération internationale des auteurs de

films (qui regroupait des scénaristes et des réalisateurs).

L'argent était un des enjeux des luttes autour du statut juridique d'auteur de film. Le droit d'auteur français et le copyright étatsunien accordent aux auteurs un monopole de reproduction et de diffusion des œuvres que les auteurs peuvent céder en contrepartie d'une rémunération dans certains cas plus avantageuse que le salariat. Les prétendants au statut d'auteur français ont cherché à obtenir, en tant qu'auteurs, une rémunération corrélée aux recettes ou profits générés par les films. Les luttes autour du statut juridique d'auteur étaient également des luttes pour la reconnaissance ou l'accumulation de capital symbolique : le statut d'auteur distingue ceux qui en bénéficient du reste du personnel cinématographique en leur attribuant l'essentiel de la valeur des œuvres et en leur permettant d'associer leurs noms à ceux des films. L'inscription des noms des auteurs aux génériques et dans les publicités des films a fait l'objet de procès et a compté parmi les premières revendications des organisations professionnelles. Les profits symboliques associés à ce statut étaient susceptibles d'accroître les revenus des auteurs et leur pouvoir sur le reste du personnel. Ce pouvoir était le troisième enjeu des luttes autour du droit d'auteur et du copyright. En France comme aux États-Unis, des organisations professionnelles de réalisateurs et de scénaristes ont revendiqué un « droit moral " leur permettant d'empêcher certaines modifications de leurs œuvres comme le remontage des

films par les producteurs et les diffuseurs.

Les luttes de définition de l'auteur de film n'ont pas été circonscrites aux tribunaux et aux négociations autour du droit d'auteur et du copyright. Les mêmes groupes professionnels ont cherché à obtenir
Producers' Associations and the International Federation of Film Authors (which represented screenwriters and directors).

Authorship claims had financial motives. French and American copyright laws grant authors with a monopoly over the reproduction and diffusion of their works. They may transfer their property rights in exchange for compensation that is in some cases more profitable than a wage. French screenwriters and directors sought as authors to obtain compensation correlated with the revenue or profits derived from the films. Authorship and ownership claims also attempted to accumulate recognition or symbolic capital: the author status distinguishes those who benefit from it from the rest of the personnel by attributing the former most of the aesthetic value of the motion pictures and allowing them to associate their names with those of the films. The mention of authors' names in film credits and advertising has been the subject of litigation and was one of the first claims of professional associations. The symbolic benefits associated with authorship may also increase the authors income and power over other workers. Professional power was also at stake in copyright battles. In France and the US, societies of directors and screenwriters claimed a "moral right" allowing them to oppose changes to their work, such as re-editing by producers and cinema owners.

Authorship conflicts also took place in arenas other than copyright negotiations. Members of the same occupations tried to secure collective agreements providing for rights close to the ones they 
que des conventions collectives leur reconnaissent des droits proches de ceux qu'ils revendiquaient dans les négociations au sujet du droit de propriété artistique. La définition des auteurs de films a également été débattue dans des revues culturelles et cinématographiques qui se sont développées à partir du début du XXe siècle (Abel 1988, Frey 2015, Gauthier 2008). Dans ces publications également, des producteurs, des scénaristes et des metteurs en scène se sont présentés comme des auteurs, ce qui permettait d'accroître leur reconnaissance par le public et les critiques de cinéma. À en croire de nombreux témoignages de l'époque et récits autobiographiques, les luttes de définition de l'auteur se sont également déroulées dans le cadre de la fabrication des films, où les producteurs, les scénaristes et les réalisateurs se disputaient l'imposition de choix concernant par exemple le remaniement des scénarios, le casting et le montage.

La définition des auteurs de films a occupé d'autres acteurs que les scénaristes, les producteurs et les réalisateurs. Des groupes professionnels moins hauts placés dans les hiérarchieséconomiques et symboliques du cinéma, comme les opérateurs et les monteurs, ont valorisé leurs métiers en contestant l'attribution des films à une seule personne, ou au contraire en se présentant comme au service du réalisateur (Crisp 1987, Denis 2011, Marion 1949, Morrissey 2011, Namburg 1938). Les luttes d'attribution du statut juridique d'auteur et de propriétaire des films ont également opposé des experts de la propriété littéraire et artistique soutenant tel ou tel groupe de prétendants. Dans la presse, l'attribution des films à des auteurs a été opérée par des critiques de cinéma, qui transposèrent au cinéma des principes de classement et de hiérarchisation des œuvres employés par les critiques littéraires et artistiques (Abel 1985, Gauthier 2008). Comme on peut s'en convaincre à la lecture d'anthologies de critiques d'avant-guerre, l'attribution des films à des auteurs, et tout particulièrement aux metteurs en scène, était très courante avant l'existence des Cahiers du cinéma, et cela en France comme aux États-Unis (Abel 1988, Hochman 1982). claimed in copyright negotiations. The definition of film authors was also debated in cultural and film publications that appeared in the early twentieth century (Abel 1988; Frey 2015; Gauthier 2008). In the film press, producers, screenwriters, and directors presented themselves as authors, which nurtured their public and critical recognition. According to many articles and autobiographies from this period, authorship conflicts also occurred in the workplace, where producers, screenwriters and directors tried to control screenwriting, casting, editing, etc.

Film authorship was equally debated and constructed by actors other than screenwriters, producers, and directors. Workers in lower positions in the economic and symbolic hierarchies of cinema, such as cinematographers and editors, valued their work by challenging the attribution of films to one person only, or conversely by presenting themselves as collaborators of the director (Crisp 1987; Denis 2011; Marion 1949; Morrissey 2011; Namburg 1938). Legal experts also competed in copyright negotiations and in courts, where they supported authorship claims. In the press, motion pictures were attributed to authors by film critics, who borrowed ways to classify and evaluate art works from literary and art critics (Abel 1985; Gauthier 2008). Pre-war critical anthologies clearly attest that both in France and the US, the attribution of motion pictures to individuals, especially to directors, was very common before Cahiers du cinema even existed (Abel 1988; Hochman 1982). 


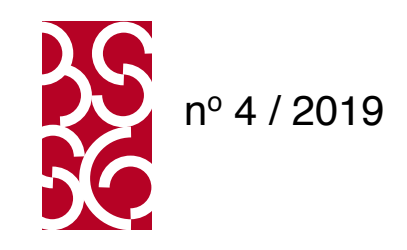

Fig. 1.Portrait et nom d'auteur en couverture de La Revue du cinéma (1930).

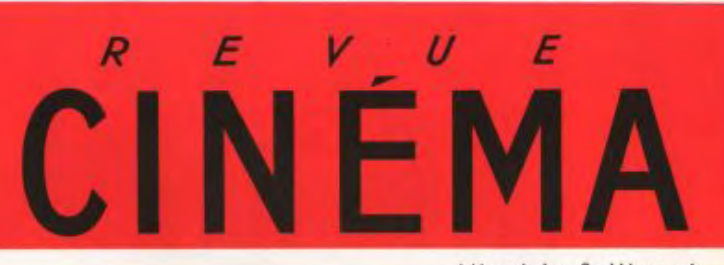

Librairie Gallimard 43,r. de Beaune, Paris-7

Annèe No 8

Mars 1930

nrf

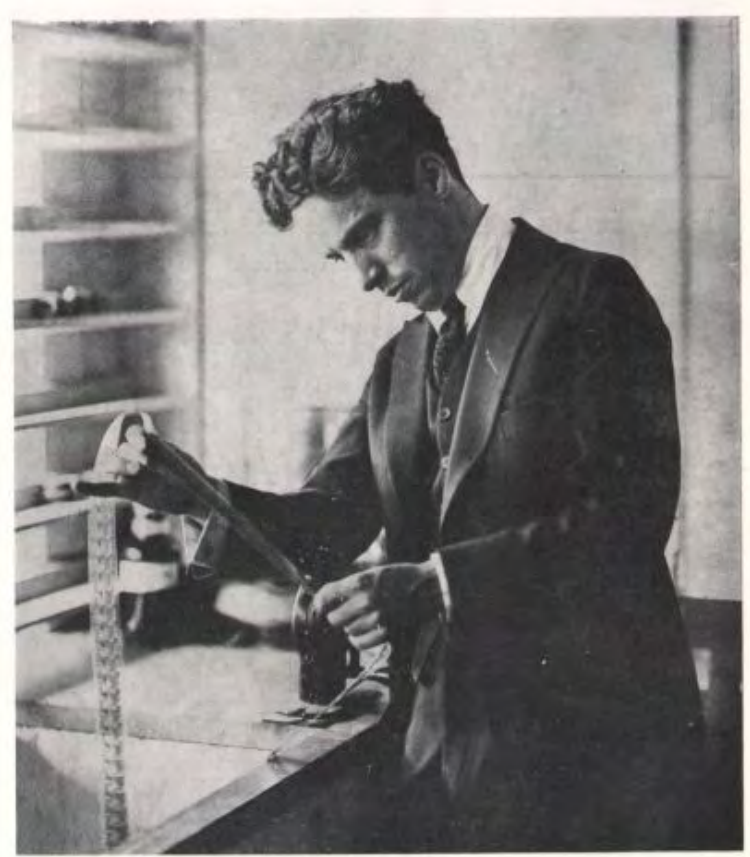

Fig. 1. Portrait and name of author on the cover of La Revue du cinéma (1930). Source : Calindex 

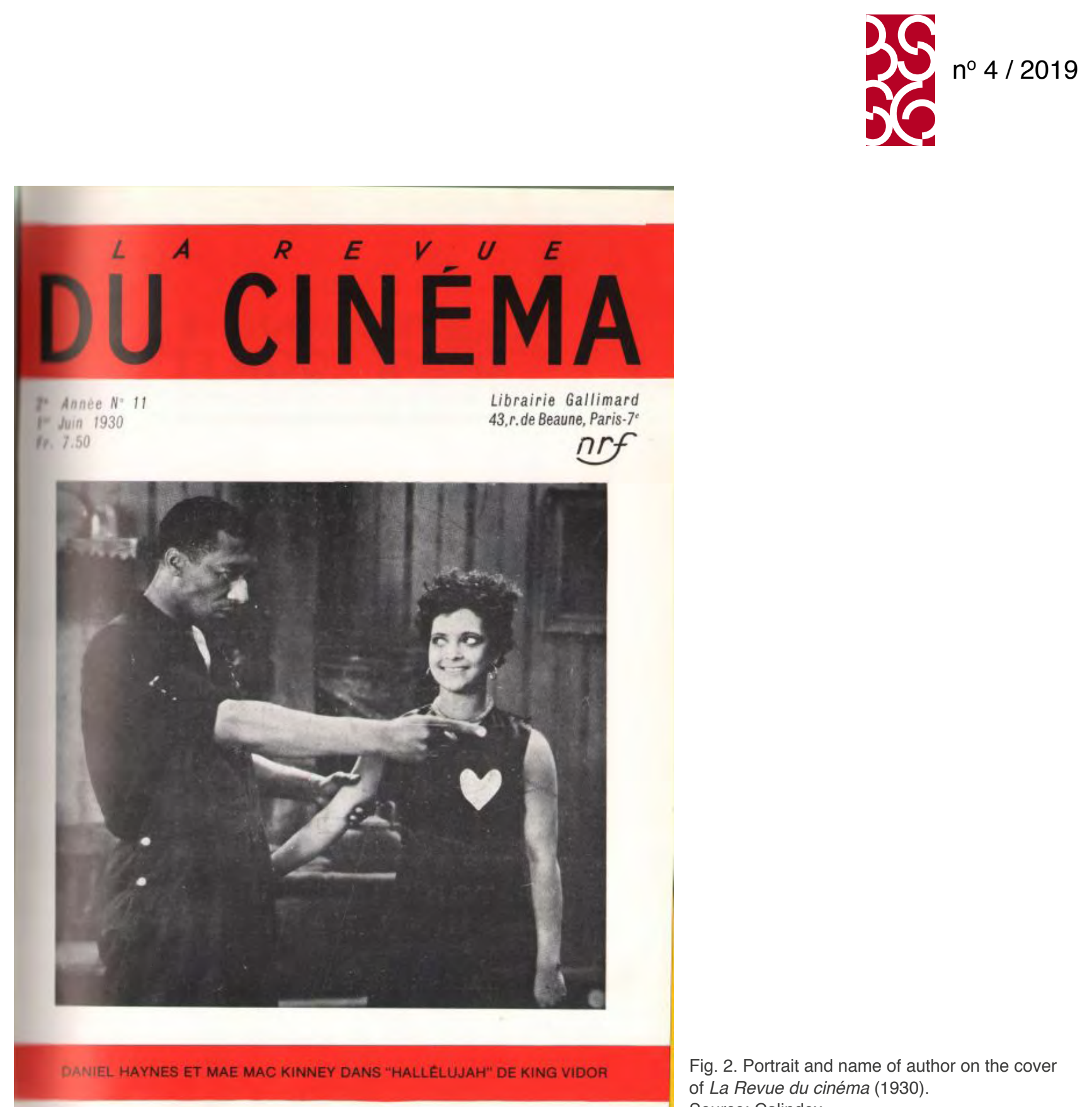

Fig. 2. Portrait and name of author on the cover of La Revue du cinéma (1930). de La Revue du cinéma (1930). Source : Calindex. Source: Calindex. 
Les luttes de définition de l'auteur de film présentent des points communs avec les luttes de jurisdiction conceptualisées par Andrew Abbott (1988 : 59-85). Selon ce dernier, les tâches et droits des membres d'un groupe professionnel dépendent de ses concurrences avec d'autres groupes pour le monopole de domaines de compétence - ces luttes se déroulant dans trois arènes principales : les lieux de travail, l'État et l'opinion publique. Les luttes de définition de l'auteur de film contrastent cependant avec les luttes de jurisdiction au sens où leurs acteurs se divisaient moins au sujet de la répartition du travail et du monopole de certaines compétences que sur la valeur de leurs tâches et leur contribution à la valeur des films. Les prétendants au statut d'auteur de film ont chacun cherché à imposer des représentations antagonistes et hiérarchisées de la division du travail cinématographique, ce qui rapproche leurs luttes de celles portant sur la définition d'autres groupes sociaux comme les classes et catégories socioprofessionnelles (Boltanski 1982, Bourdieu 1984). Comme on va le voir, les producteurs, les scénaristes et les réalisateurs se sont également affrontés au nom de différentes conceptions du cinéma et de ses relations avec d'autres champs de production culturelle.

\section{Chefs d'orchestre, écrivains et compositeurs} de l'écran

Plusieurs travaux ont déjà montré que l'autonomisation d'un champ artistique était favorisée par l'affirmation de sa singularité par rapport à d'autres arts et par des comparaisons avec des arts plus anciens et légitimes (Boltanski 1975 : 42, Heinich \& Shapiro 2012 : 294-295). On observe le même phénomène dans le cas des producteurs, des scénaristes et des réalisateurs, qui ont prétendu être les seuls auteurs d'un art original tout en comparant leurs métiers à ceux d'auteurs, d'artistes et d'entrepreneurs d'autres champs.
Authorship battles have some similarities with the jurisdictional conflicts conceptualized by Andrew Abbott (Abbott 1988: 5985). He contended that the tasks and rights of the members of a profession depend on its competitions with other groups for the monopoly over areas of jurisdiction. These struggles over jurisdiction unfold in three main arenas: the workplace, the state and public opinion. Yet the struggles over the definition of film authors contrast with struggles over jurisdiction in the sense that their actors were not so much divided regarding the distribution of tasks and the monopoly over certain competencies as about their contribution to the value of films. Screenwriters, producers and directors have each sought to impose opposite representations of film production and its hierarchies. In this way, authorship conflicts resemble struggles over the definition of other social groups, such as class and socio-economic groups (Boltanski 1982; Bourdieu 1984). As we will see, producers, screenwriters, and directors also promoted different conceptions of cinema and of its relations with other fields of cultural production.

\section{Conductors, Writers, and Composers for the Screen}

Several studies have shown that the autonomization of an artistic field is favoured by the affirmation of its singularity in relation to other arts and by comparison to older, more legitimate artistic activities (Boltanski 1975:42; Heinich \& Shapiro 2012: 294-295). This phenomenon can be observed in film authorship battles. Producers, screenwriters, and directors claimed to be the sole authors of an original art while comparing their activities to those of authors, artists, and entrepreneurs working in other fields. 
Les producteurs se sont définis comme des auteurs au nom du caractère collectif et coûteux de la fabrication d'un film, et cela en insistant sur les différences entre le cinéma et les arts dits individuels comme la littérature ou la peinture. En 1951, leur fédération internationale a adopté une charte de la production cinématographique affirmant qu'un film était une œuvre collective, qui relevait de l'esprit autant que de la technique et de l'industrie et qui ne pouvait être assimilée à aucune autre œuvre, même lorsqu'il s'agissait de l'adaptation d'une autre œuvre littéraire et artistique (Le Film français 1951). En accord avec leur conception du cinéma comme art et comme industrie, des porte-paroles des producteurs ont revendiqué le statut d'auteur et la propriété des films en se comparant à des entrepreneurs. En 1958, lors de la révision de la législation états-unienne sur le copyright, un porteparole de l'organisation des producteurs, la MPAA, a avancé que le seul auteur était « l'entrepreneur ou producteur, qui, dans le but de la fabrication d'un film, a financé et coordonné le travail intellectuel de diverses personnes employées non seulement pour créer ou adapter des sources littéraires, dramatiques ou musicales utilisées pour le film, mais aussi le travail intellectuel de création artistique ou d'interprétation de ceux ayant joué dans le film et dirigé ces interprétations " (Copyright Office 1958). Dans un article paru en 1931 dans Le Temps et republié en 1951 dans Le Film français, le président de la Chambre syndicale de la cinématographique et de la Fédération internationale des associations de producteurs de films, Charles Delac, a assimilé le producteur à un auteur, un entrepreneur et à un " véritable chef d'orchestre, dosant chaque apport, pour qu'aucune des parties de l'œuvre ne soit sacrifiée aux autres, apportant à chaque instant, dans ce milieu de création fiévreuse, son esprit critique, le calme de sa pondération et sa connaissance des besoins de la cinématographie » (Delac 1951).
To define themselves as authors, producers stressed the collective and costly nature of filmmaking. They also emphasized the differences between motion pictures and artworks attributed to individuals such as novels and paintings. In 1951, the producers' international federation adopted a charter for film production which stated that a motion picture is a work produced collectively, $-\mathrm{a}$ work of the mind just as much as a technical and industrial good (Le Film français 1951). This charter also stated that a motion picture cannot be reduced to another work, even in the case where a literary or artistic work is being adapted. In keeping with their view of cinema as an art and an industry, spokespersons for producers presented themselves as entrepreneurs to justify their status of authors and owners. In 1958, in the negotiation that led to the 1976 Copyright Act, the Motion Pictures Association of America claimed that the sole author was "the entrepreneur or producer, who, for the purpose of this recordation of a single captured rendition, has financed and coordinated the intellectual labours of various persons employed not only to create or adapt source materials of a literary, dramatic, or musical nature for the rendition, but also the intellectual labours of an artistic and interpretative character of those who have performed therein and directed such performances." (Copyright Office 1958). In a piece published in 1931 in Le Temps and reproduced in 1951 in Le Film français, the president of the trade union body Chambre syndicale de la cinématographie and of the International Federation of Film Producers' Associations, Charles Delac, likened the producer to an author, an entrepreneur, and a "genuine conductor, weighing each contribution so that none of the parts of the work is sacrificed to others; in this feverishly creative environment, the producer constantly offers critical input, calm, and moderation, as well as his knowledge of the needs of cinema" (Delac 1951) 


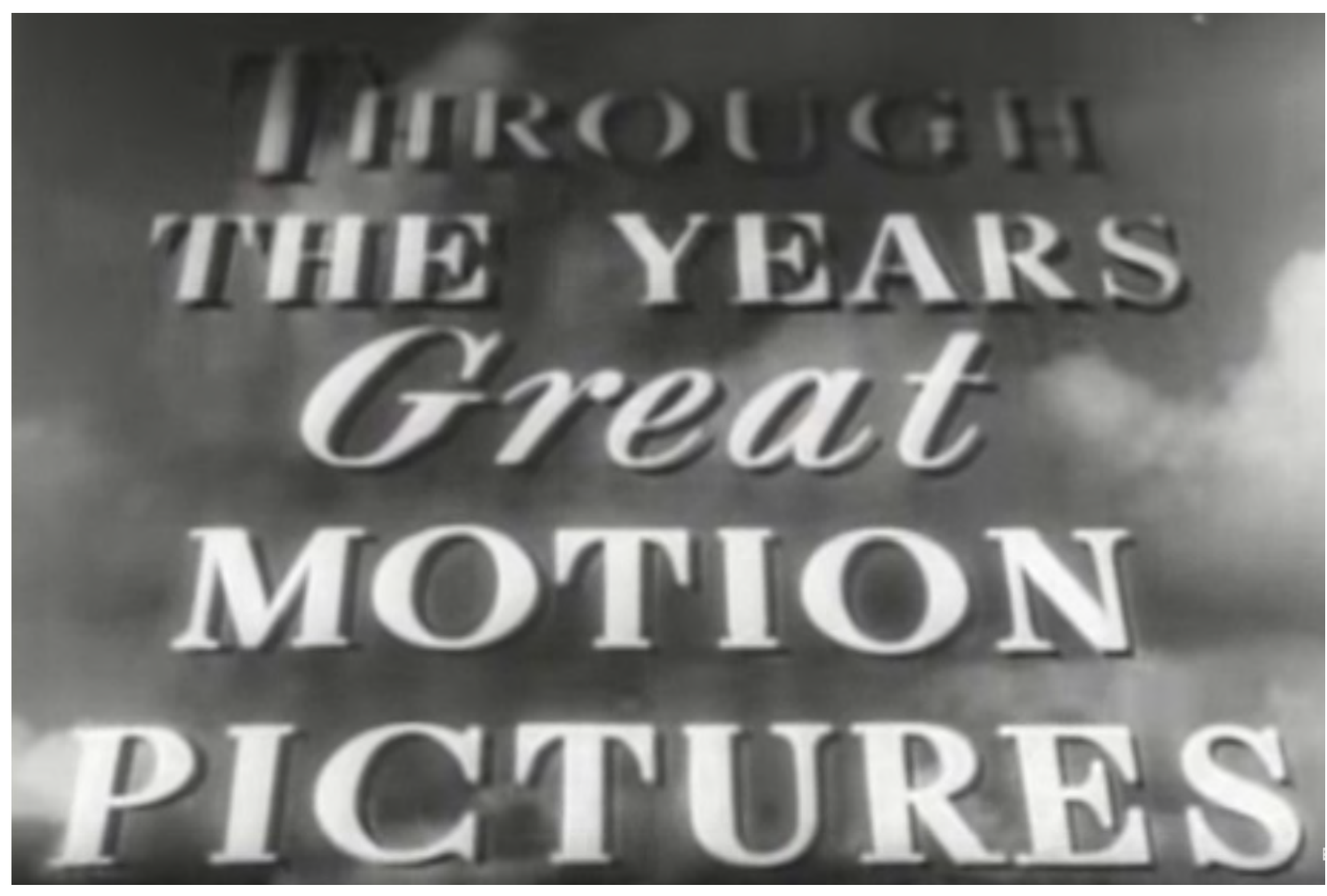

Vidéo 1
Bande-annonce d'un film du producteur Samuel Goldwyn : The Best Years of Our Lives (1946).

Trailer for a film produced by Samuel Goldwyn The Best Years of Our Lives (1946). Source : YouTube. 
Les porte-paroles des écrivains et des scénaristes ont quant à eux défendu le statut d'auteur en définissant les films comme des représentations ou mises en images de leurs écrits. En 1925, devant une commission de la Chambre des représentants, l'écrivaine et scénariste Alice Duer Miller a déclaré que le scénario était au film ce qu'était le manuscrit au livre et la pièce à la représentation théâtrale (House of Representatives 1925 : 61). Pour le prouver, elle a décrit une scène de tournage et cité un scénario qui en prévoyait le décor, les personnages, leurs mouvements, leurs dialogues, leurs émotions et la manière de les filmer. En 1928, à l'occasion de la révision de la convention de Berne, le président de la Société des auteurs de films, Michel Carré, a affirmé que l'importance de l'écrivain ne pouvait être sous-estimée car « au cinéma, comme au théâtre et dans le roman, c'est le sujet qui est tout » (La Cinématographie française 1928). À la fin des années 1920 et au début des années 1930, la généralisation du cinéma parlant a été salué par des dramaturges et scénaristes comme Marcel Pagnol et Robert Sherwood (Pagnol 1991, Sherwood 1929), qui y voyaient la promesse d'un nouvel art dramatique ayant pour seul auteur le scénariste. En 1936, lors d'une audition parlementaire consacrée à la convention de Berne, le scénariste John Howard Lawson a avancé que le cinéma parlant et ses dialogues rendaient l'importance de l'auteur du scénario plus apparente qu'elle ne l'était auparavant, alors que le cinéma était dominé par les réalisateurs puis par des producteurs, qu'il jugeait responsable de la mauvaise qualité des films (House of Representatives 1936).

Tout en définissant les auteurs de films par analogie avec le théâtre et la littérature, des écrivains et scénaristes ont insisté sur les spécificités de l'écriture pour ce médium. Dès 1921, l'écrivain et scénariste Somerset Maugham affirmait la primauté de l'auteur du scénario sur le metteur en scène en considérant que les conventions de l'écriture cinématographique distinguaient celle-ci de l'écriture d'un livre ou d'une pièce (Maugham 1921). Tout en défendant l'idée
Spokespersons for writers and screenwriters, on the other hand, justified their author status by defining motion pictures as representations or translations of their writings into images. In 1925, speaking before a House of Representatives committee, writer and screenwriter Alice Duer Miller argued that a screenplay is to a film what a manuscript is to a book and a play to a theatrical performance (House of Representatives 1925: 61). To prove her point, she described the shooting of a scene, quoting a screenplay that included specifications for decor, characters, their movements, dialogues, emotions, as well as ways of filming them. In 1928, commenting on the Berne Convention revision, president of the Société des auteurs de films Michel Carré claimed that the importance of the writer could not be underestimated, as "in cinema, as in theatre and in literature, subject is everything" (La Cinématographie française, 1928). In the late 1920s and early 1930s, the development of sound film was heralded by playwrights and screenwriters such as Marcel Pagnol and Robert Sherwood (Pagnol 1991; Sherwood 1929). They saw sound film as the promise of a new dramatic art where the screenwriter would be the sole author. In 1936, during a congressional hearing on the Berne Convention, screenwriter John Howard Lawson argued that talkies and their dialogues made the importance of the screenwriter more apparent than it used to be when Hollywood was dominated by directors and then producers, whom he held responsible for the poor quality of motion pictures (House of Representatives 1936).

While defining film authors by referring to theatre and literature, writers and screenwriters emphasized the specificities of writing for this medium. As early as 1921, writer and screenwriter Somerset Maugham claimed that the screenwriter was more important than the director on the grounds that the conventions of writing for film were different than for novels and plays (Maugham 1921). Whilst defending the idea that sound film would become the dramatist's 
que le cinéma parlant deviendrait l'art de l'auteur dramatique, Marcel Pagnol et Robert Sherwood ont eux aussi distingué l'écriture de scénarios de l'écriture de pièces. Pour le dramaturge états-unien, un film parlant n'était pas réductible à l'enregistrement d'une pièce de théâtre et s'en distinguait autant que d'une fugue. Robert Sherwood regrettait la multiplication des adaptations de pièces de Broadway et estimait que les anciens espoirs d'Hollywood ne savaient ni écrire ni filmer des dialogues, tandis que les jeunes espoirs de Broadway ne comprenaient pas l'art de l'expression au moyen d'images animées (notamment le principe du gros plan). Selon Marcel Pagnol, le cinéma parlant allait permettre aux auteurs dramatiques de dépasser Molière et Shakespeare en sautant la rampe, en tournant autour de la scène, en faisant éclater les murs du théâtre et en mettant en morceau le

décor ou l'acteur.

Comme les autres prétendants au statut d'auteur, les réalisateurs ont défini le cinéma comme un art spécifique, tout en comparant leur activité avec celles d'artistes et d'auteurs d'autres champs. Ils se sont distingués des metteurs en scène de théâtre auxquels les apparentaient des porte-paroles des scénaristes et des écrivains. Dès le début des années 1920, Germaine Dulac a prôné l'abolition du qualificatif de «metteur en scène » au profit de celui de «visualisateur », qu'elle définissait comme l'« artiste qui, sur un thème, compose et rythme l'image, verbe du film » (Dulac 1994). La même réalisatrice a ensuite proposé les termes de cinégraphiste, de compositeur visuel et de cinéaste. En 1928, à l'occasion de la révision de la convention de Berne, Léon Poirier a préféré le terme de compositeur à celui de metteur en scène, qu'il jugeait inepte car emprunté au vocabulaire théâtral (La Cinématographie française 1928). Plus généralement, les réalisateurs ont insisté sur l'originalité du cinéma par rapport à d'autres arts, et tout particulièrement vis-à-vis de la littérature et du théâtre. En 1924, Germaine Dulac définissait le cinéma comme art, Marcel Pagnol and Robert Sherwood also made a distinction between writing scripts and writing plays. To the American playwright, a talking film could not be described simply as the recording of a theatrical play; a movie was as independent of a play as it was of a fugue. Robert Sherwood decried the adaptation of many plays from Broadway. He believed that Hollywood's former white hopes were unable to write and direct dialogue, while newcomers from Broadway did not understand the art of expression in moving pictures (particularly close-ups). According to Marcel Pagnol, talkies would enable dramatists to surpass Molière and Shakespeare, making it possible to jump over handrails, turn around the stage, tear down the walls of the theatre and break decors and actors into pieces.

Like screenwriters and producers, directors defined cinema as a new art, while comparing their activity to the work of artists and authors in other fields. They distinguished themselves from the stage directors with whom they were associated by the spokespersons of screenwriters and writers. In the early 1920s, Germaine Dulac called for the abolishment of the term metteur en scène (director, a term also used for the theatre) and its replacement by visualisateur (literally, visualizer). She defined the visualisateur as the "artist, who, on a given theme, composes and delivers images, which are the film's words, their flow" (Dulac 1994). The same director then advocated for the terms cinégraphiste, compositeur visuel (visual composer), and cinéaste. In 1928, while the Berne Convention was being revised, Léon Poirier elected to use compositeur over metteur en scène, deeming the latter term unsuitable on the grounds that it was borrowed from the vocabulary of theatre (La Cinématographie française, 1928). More broadly, directors emphasized the originality of cinema compared with other arts, especially literature and theatre. In 1924, Germaine Dulac defined cinema as a "wonderful 
un « art merveilleux qui se pare des autres arts comme d'un luxe superflu », même s'il pouvait « emprunter à l'architecture ses lignes harmonieuses, à la sculpture ses belles formes, à la musique son rythme, à la peinture, ses savants éclairages, bientôt peut-être, ses couleurs » (Dulac 1994 : 45). L'année suivante, elle reprochait à

« la littérature qui s'est crue maîtresse de réduire le cinéma à ses lois » (Dulac 1994 : 53-54).

Alors que des scénaristes et écrivains voyaient dans le cinéma la promesse d'un nouvel art dramatique, des metteurs en scène ont de nouveau insisté sur les différences entre le théâtre et le cinéma. En réponse aux vues de Marcel Pagnol, René Clair a estimé en 1929 que le cinéma parlant devait demeurer un art plus distinct encore du théâtre que ne l'était le cinéma muet : les mots du cinéma n'avaient d'importance qu'en relation avec l'image, tandis qu'au théâtre ce qui était vu n'existait que pour servir les mots des comédiens (Abel 1988 : 39-40). Selon lui, le cinéma parlant doublait l'importance du réalisateur, qui devenait responsable à la

fois de l'image et du son.

Des réalisateurs états-uniens se sont également définis comme des auteurs en définissant le cinéma comme un art original et en comparant leur activité avec celle d'artistes d'autres champs. C'est le cas des deux premiers présidents de la guilde des réalisateurs états-uniens, King Vidor et Frank Capra. Le premier a écrit que le réalisateur devait être à la fois un écrivain, un dramaturge, un monteur, un technicien et un musicien - le paradoxe du cinéma étant qu'il réunissait tous les arts sans se réduire à l'un d'entre eux (Vidor 1972 : 36 et 229). Le second a présenté le cinéma comme un nouveau langage et comme un nouvel art, qui n'avait qu'un auteur, à la manière des pièces et des compositions musicales

(Capra 1997 : 33-34) art that dons the robes of other arts as a superfluous luxury," even if it could "borrow from architecture its harmonious lines, from sculpture its pretty forms, from music its rhythm, from painting its elaborate use of lighting, and soon maybe its colors" (Dulac 1994: 45). The following year, she blamed literature for "believing it had the right to reduce cinema to its own laws" (Dulac 1994: 53-54).

While screenwriters and writers saw in cinema the promise of a new dramatic art, some directors again emphasized the differences between theatre and cinema. In response to Marcel Pagnol's views, René Clair argued in 1929 that sound film must remain even more distinct from theatre than silent film used to be: in cinema, words only mattered in relation to the image, whereas in theatre, what was seen only existed to serve the actors' words (Abel 1988 39-40). According to him, talking cinema made the director doubly important, as he was now in charge of both image and sound.

American directors also defined themselves as authors by defining cinema as an original art and comparing their own work with the work of artists in other fields. This was the case of the first two presidents of the Directors Guild of America, King Vidor and Frank Capra. The former wrote that the director had to be a writer, a playwright, an editor, a technician, and a musician all at oncethe paradox of cinema being that it brings all arts together without being reduced to any of them (Vidor 1972: 36 and 229). The latter presented cinema as a new language and a new art, with only one author, like theatrical plays and musical compositions (Capra 1997: 33-34). 


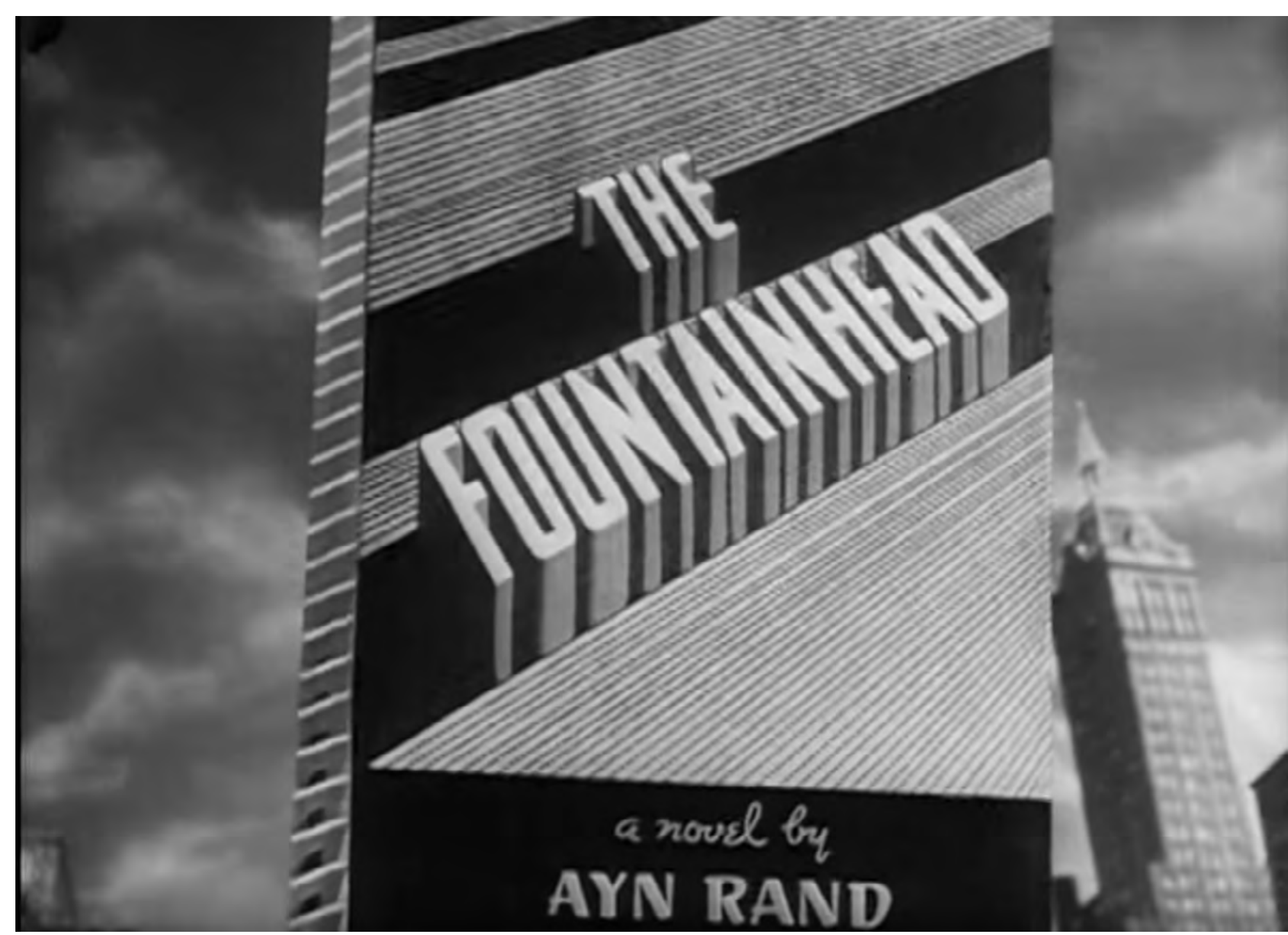




\section{DISQUE}

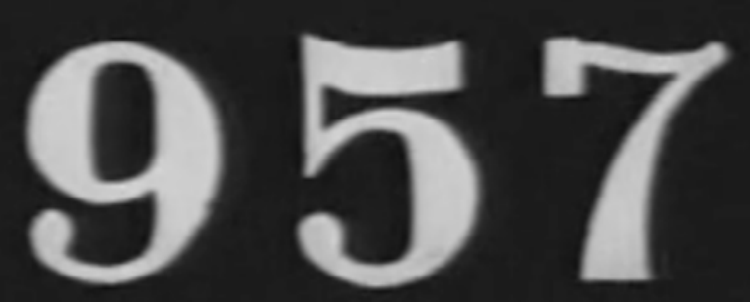

impressions visuelles

de

Vidéo 3

«Impressions visuelles de Germaine Dulac » : Disque 957 (1928). Source : YouTube.
Video 3

"Impressions visuelles de Germaine Dulac": Disque 957 (1928). Source: YouTube. 


\title{
A STUDY IN CHOREOGRAPHY FOR CAMERA
}

\author{
(SILENT)
}




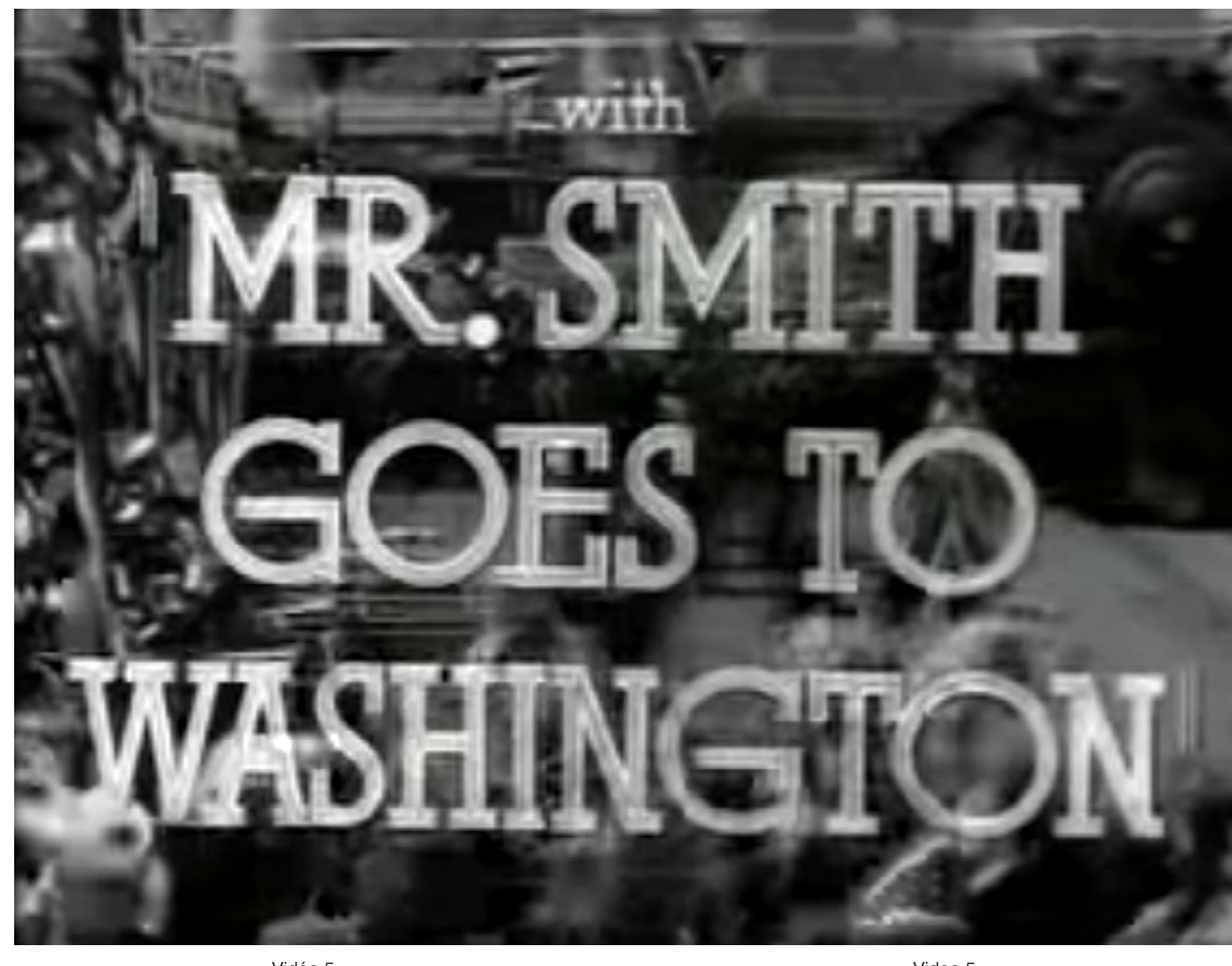


Comment expliquer que différents groupes professionnels se soient définis comme les auteurs d'œuvres d'un art nouveau, tout en se comparant aux auteurs, artistes et professionnels d'autres domaines d'activité ? Leurs discours ont d'abord été favorisés par ceux d'autres acteurs intervenant dans les luttes de définition des auteurs de films. Leurs prises de position leur permettaient de contester celles des autres prétendants au statut d'auteur et de propriétaire des œuvres. Elles étaient ajustées à leurs revendications : les producteurs, les scénaristes et les réalisateurs ont cherché à obtenir les mêmes droits de propriété que ceux dont bénéficiaient les entrepreneurs, les artistes et les auteurs auxquels ils se comparaient. Les discours des prétendants au statut d'auteur s'accordaient aussi avec ceux de critiques. On l'a évoqué, la critique cinématographique a rapidement fait de la « fonction-auteur » l'un de ses premiers principes de classement et de hiérarchisation des œuvres, en privilégiant l'attribution des films aux réalisateurs. Tout comme les prétendants au statut d'auteur et à la suite d'écrivains comme Canudo (Andreazza 2006, 2018), les critiques de cinéma ont eux aussi défini le cinéma comme un art distinct des autres, ce qui leur permettait de faire valoir des compétences qui les distinguaient de critiques d'autres disciplines artistiques. Qu'ils rapprochent le cinéma d'autres activités plus prestigieuses ou qu'ils lui prêtent des vertus et promesses inatteignables par les auteurs et artistes d'autres champs, les discours des prétendants au statut d'auteur et des critiques de cinéma étaient susceptibles d'accroître la légitimité culturelle du cinéma par rapport à d'autres activités, à une époque où elle était contestée par des écrivains, des critiques et des intellectuels « cinéphobes 》(Baumann 2007 : 113-117, Gauthier 1999 : 240-242, Restoueix 1995, Sherman 2016). Accordés ou opposés aux discours de critiques et d'autres professionnels, les définitions du cinéma promue par les prétendants au statut d'auteur leur servaient donc à assurer leur position dominante dans une hiérarchie professionnelle en formation tout en œuvrant à la légitimation culturelle du cinéma. Leurs prises de position étaient ainsi susceptibles d'accroître les rétributions économiques et symboliques que leur procuraient leur activité.
How to explain that several professional groups defined themselves as the authors of works in a new art, while comparing themselves to the authors, artists, and professionals working in other fields? First, their discourses were fuelled by those of other actors involved in authorship battles. They challenged the views of members of other occupations who were also claiming the authorship and ownership of motion pictures. Also, their views of cinema were shaped by their claims: producers, screenwriters, and directors sought to obtain the property rights granted to the entrepreneurs, artists, and authors with whom they compared themselves. The discourses of producers, screenwriters, and directors also echoed those of critics. As mentioned above, film criticism quickly made the "author function" one of its main tools for classifying and evaluating motion pictures, generally opting to attribute films to directors. Like selfproclaimed authors and in the wake of writers such as Canudo (Andreazza 2006; 2018), film critics too defined cinema as a new art, which enabled them to claim competencies that distinguished them from critics in other artistic disciplines. Whether they likened cinema to more prestigious activities or celebrated virtues and promises that were out of reach for authors and artists in other fields, the discourse of film "authors" and film critics was likely to increase the cultural legitimacy of cinema at a time when it was challenged by "cine-phobic" writers, critics, and intellectuals (Baumann 2007: 113-117; Gauthier 1999: 240-242; Restoueix 1995; Sherman 2016). Whether they concurred or clashed with the discourse of critics and other professionals, the definitions of cinema promoted by self-proclaimed authors ensured their dominant position in a developing professional hierarchy while promoting the cultural legitimation of cinema. Their discourse was thus likely to increase the economic and symbolic rewards resulting from their activity. 
Les définitions du cinéma et de l'auteur de film promues par les scénaristes, les réalisateurs et les producteurs s'expliquent aussi par leurs activités et trajectoires professionnelles. Les membres et porteparoles de ces groupes ont pu comparer leur travail à celui d'auteurs et de professionnels aux « faisceaux de tâches » (Becker 1988) assez semblables aux leurs, comme les écrivains dans le cas des scénaristes. De telles comparaisons, et plus généralement les luttes de définition des auteurs et de la valeur des films, ont été favorisées par les formations et activités antérieures et parallèles des producteurs, des scénaristes et des réalisateurs. Luc Boltanski a montré que la constitution d'un champ de la bande-dessinée et la production de bandes dessinées « d'auteur » a été favorisée par les formations et carrières ratées de certains dessinateurs dans d'autres disciplines artistiques (Boltanski 1975 : 38). Le même phénomène s'observe dans le cas du cinéma. Certains scénaristes pouvaient d'autant mieux se considérer comme des auteurs de cinéma qu'ils avaient préalablement ou parallèlement écrit des livres et des pièces. À partir des années 1910, des sociétés comme le Film d'Art, la Société cinématographique des auteurs et gens de lettres et Eminent Authors (une filiale de Goldwyn) ont cherché à tirer profit de la notoriété d'écrivains à succès, en proposant des " scénarios d'auteurs » (Carou 2002, 2013, Fine 1993, Rosten 1941 : 306-317). Les savoir-faire des écrivains ont également été utiles à l'allongement de la durée des métrages puis à la généralisation du cinéma parlant. Environ 150 écrivains publiés ont été engagés comme scénaristes à Hollywood dans les années 1930 (Fine 1993 : 12). Comme les scénaristes, les metteurs en scène de cinéma étaient nombreux à avoir exercé d'autres activités artistiques. Sans surprise étant donné leur premier intitulé de métier, les premières générations de metteurs en scène de cinéma avaient d'abord travaillé au théâtre (Bordwell et al. 1985 : 117-120, Carou 2013). De nombreux metteurs en scène en activité dans les années 1920 à 1950 avaient écrits des pièces, des poèmes ou des romans, ou appris et pratiqué la peinture, la sculpture, l'architecture et la musique (Crisp 1997: 160, 330, Duval 2016 : 106-107). Quant aux producteurs, ils pouvaient d'autant
The views of cinema and film authorship promoted by screenwriters, directors, and producers were also shaped by their professional activities and career paths. Members and spokespersons for these groups sometimes compared themselves with authors and professionalswhose "bundlesoftasks"(Becker 1988)weresomewhat similar to theirs, like novelists in the case of screenwriters. Such comparisons, and more broadly the struggles over the definition of film authors and the value of motion pictures, were favoured by the training and other activities pursued by producers, screenwriters, and directors. Luc Boltanski showed that the formation of a field of comic books and the production of "auteur comics" were favoured by the training and failed careers of some comic writers in other artistic disciplines (Boltanski 1975: 38). The same phenomenon can be observed in cinema. Some screenwriters could easily consider themselves as film authors as they were writing books and plays, or had done so. Beginning in the 1910s, societies such as Le Film d'Art, the Société cinématographique des auteurs et gens de lettres, and Eminent Authors (a Goldwyn affiliate) offered "author's screenplays" in order to benefit from the reputation of successful writers (Carou 2002; 2013; Fine 1993; Rosten 1941: 306-317). The craftsmanship of writers also came in handy as films became longer and sound film became widespread. Roughly 150 published writers were hired as screenwriters in Hollywood in the 1930s (Fine 1993: 12). Like screenwriters, many film directors had worked in other artistic fields. Unsurprisingly, the first generations of film directors had first worked in the theatre (Bordwell \& al. 1985: 117-120; Carou 2013). Many directors active in the 1920s to 1950s had written plays, poems, or novels, or learned and practiced painting, sculpture, architecture, or music (Crisp 1997: 160 and 330; Duval 2016: 106-107). As for the producers, they found it all the easier to compare themselves to entrepreneurs as many of them had founded and directed companies that marketed products and services other than films. Some of them used to be cinema owners and manufacturers of motion picture equipment (Aberdeen 2000: 26; Alberta, Gili \& al. 2001). 
plus facilement se comparer à des entrepreneurs qu'ils étaient nombreux à avoir fondé et dirigé des entreprises commercialisant d'autres produits et services que des films. On trouvait notamment parmi eux d'anciens directeurs de salles de cinéma et des fabricants de matériel cinématographique (Aberdeen 2000 : 26 ; Alberta, Gili

$$
\text { et al. 2001). }
$$

Les luttes de définition de l'auteur de film et des relations entre le cinéma, la littérature et le théâtre ont également été nourries par les adaptations cinématographiques de livres et de pièces. À la fin des années 1900, ces adaptations ont compté parmi les premières œuvres à être présentées au public comme des "films d'auteurs », en l'occurrence ceux des écrivains adaptés (Carou 2002 ; Bordwell et al. 1985 : 131-132). Les adaptations se sont multipliées lors des années et décennies suivantes, et cela à diverses fins : faciliter la production de long-métrages et de films parlants, tirer profit de la notoriété acquise par des auteurs et des œuvres littéraires et dramatiques, éviter les réprobations morales, légitimer le cinéma par rapport au théâtre et attirer un public bourgeois. En 1930, alors que se généralisait le cinéma parlant, plus de $20 \%$ des films hollywoodiens étaient des adaptations de pièces et de comédies musicales jouées à Broadway (Chabrol 2016 : 64). En France, les adaptations de romans et de pièces représentaient un peu moins de la moitié des longs-métrages tournés entre 1936 et 1959 (Crisp 1997 : 290). Les adaptations ont été un enjeu des luttes de définition de l'auteur de film, que ce soit dans la presse ou dans les négociations autour du droit de propriété cinématographique. D'une part, les écrivains et scénaristes ont revendiqué le statut d'auteur et un droit moral en dénonçant et en cherchant à contrôler les modifications apportées aux livres, pièces et scénarios par les producteurs et les réalisateurs. D'autre part, des producteurs, des scénaristes et des réalisateurs ont défendu leur qualité d'auteur en valorisant les modifications qu'ils apportaient aux livres et aux pièces, ainsi qu'en dévaluant les adaptations aux motifs qu'elles subordonnaient le cinéma à la littérature et au théâtre.
Struggles over the definition of film authors and the relations between cinema, literature, and theatre were also nurtured by adaptations of books and plays. In the late 1900s, these adaptations were among the first motion pictures to be advertised as "auteur films"-the authors being the writers whose works had been adapted for the screen (Carou 2002; Bordwell et al. 1985: 131-132). Numerous adaptations were made over the following years and decades, with various aims: facilitating the production of feature-length talking films; benefiting from the reputation acquired by novelists and playwrights; avoiding moral reprobation; legitimating cinema in comparison with the theatre and attracting a bourgeois audience. In 1930, as talking film was becoming widespread, more than 20 per cent of Hollywood films were adaptations of Broadway plays and musicals (Chabrol 2016: 64). In France, adaptations of novels and plays made up barely under half of the feature-length films produced between 1936 and 1959 (Crisp 1997: 290). Adaptations were central in authorship conflicts, both in the press and in copyright negotiations. On the one hand, writers and screenwriters claimed authorship and moral rights in order to oppose detrimental changes to books, plays, and scripts made by producers, and directors. On the other, producers, screenwriters and directors valued the changes they made in books and plays. Some of them also dismissed adaptations on the grounds that they made cinema subordinate to literature and theatre. 


\section{"Le Film d'Art" LE RETOUR D'ULYSSE}

Pièce Cinématographique de M: JULES LEMAITRE de IAcadémie Francaise

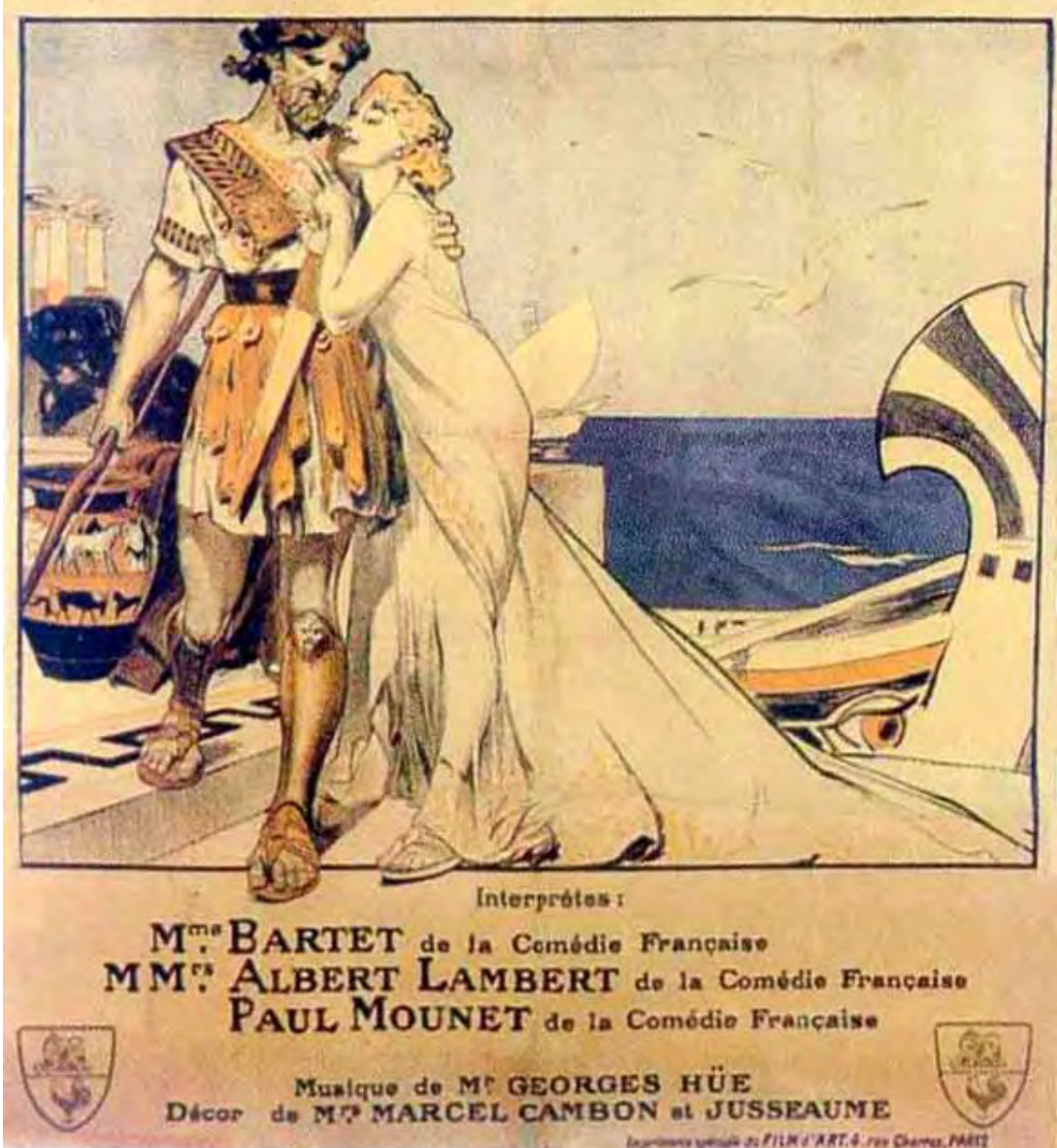

Fig. 3. Advertisement by Film d'Art. Source: Mounet-Sully and Paul Mounet. 


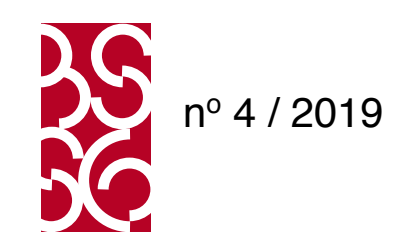

Fig. 4. Publicité de Eminent Authors. Source : Internet Movie Database.

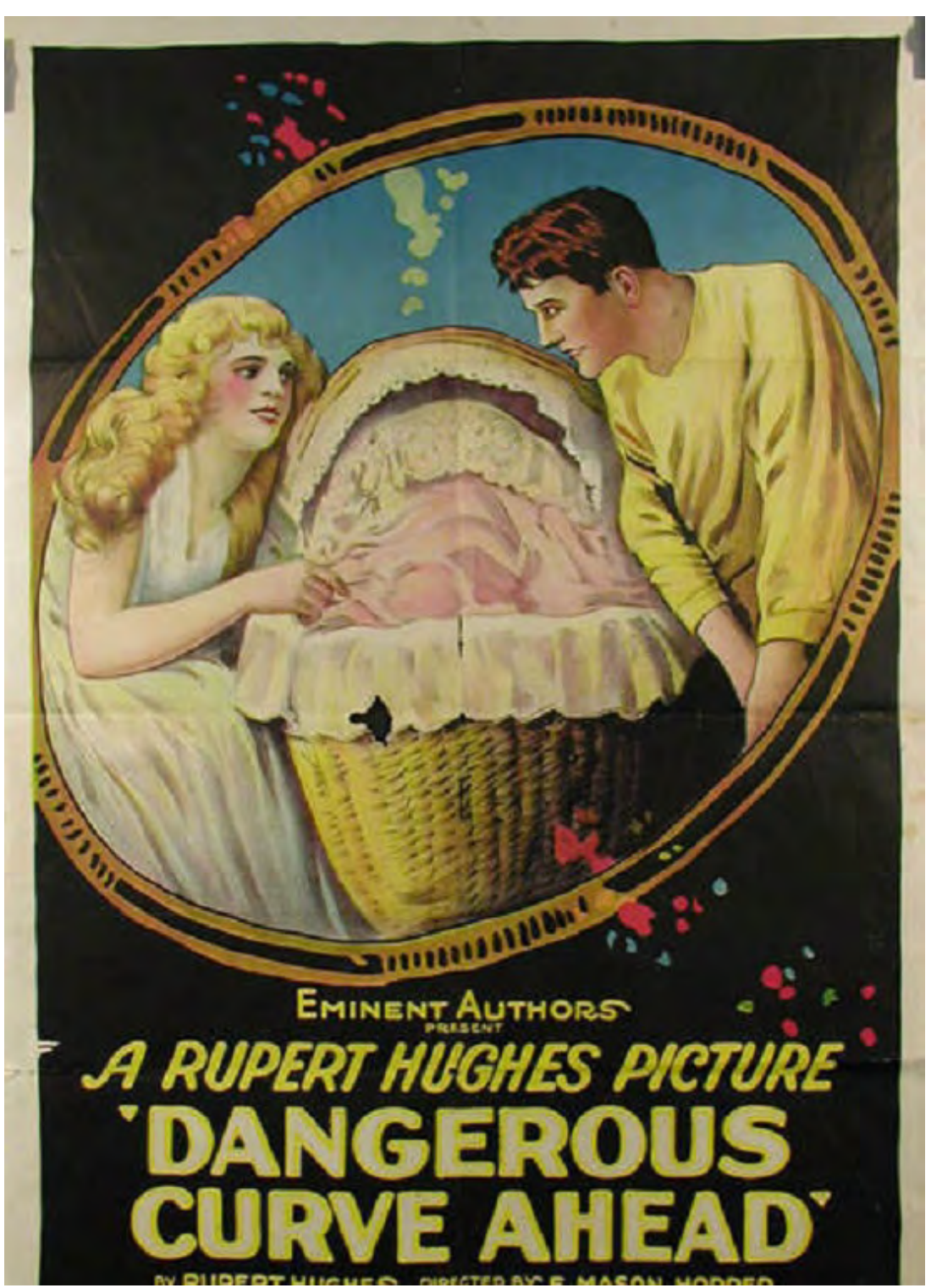

Fig. 4. Advertisement by Eminent Authors. Source: Internet Movie Database. 


\section{9

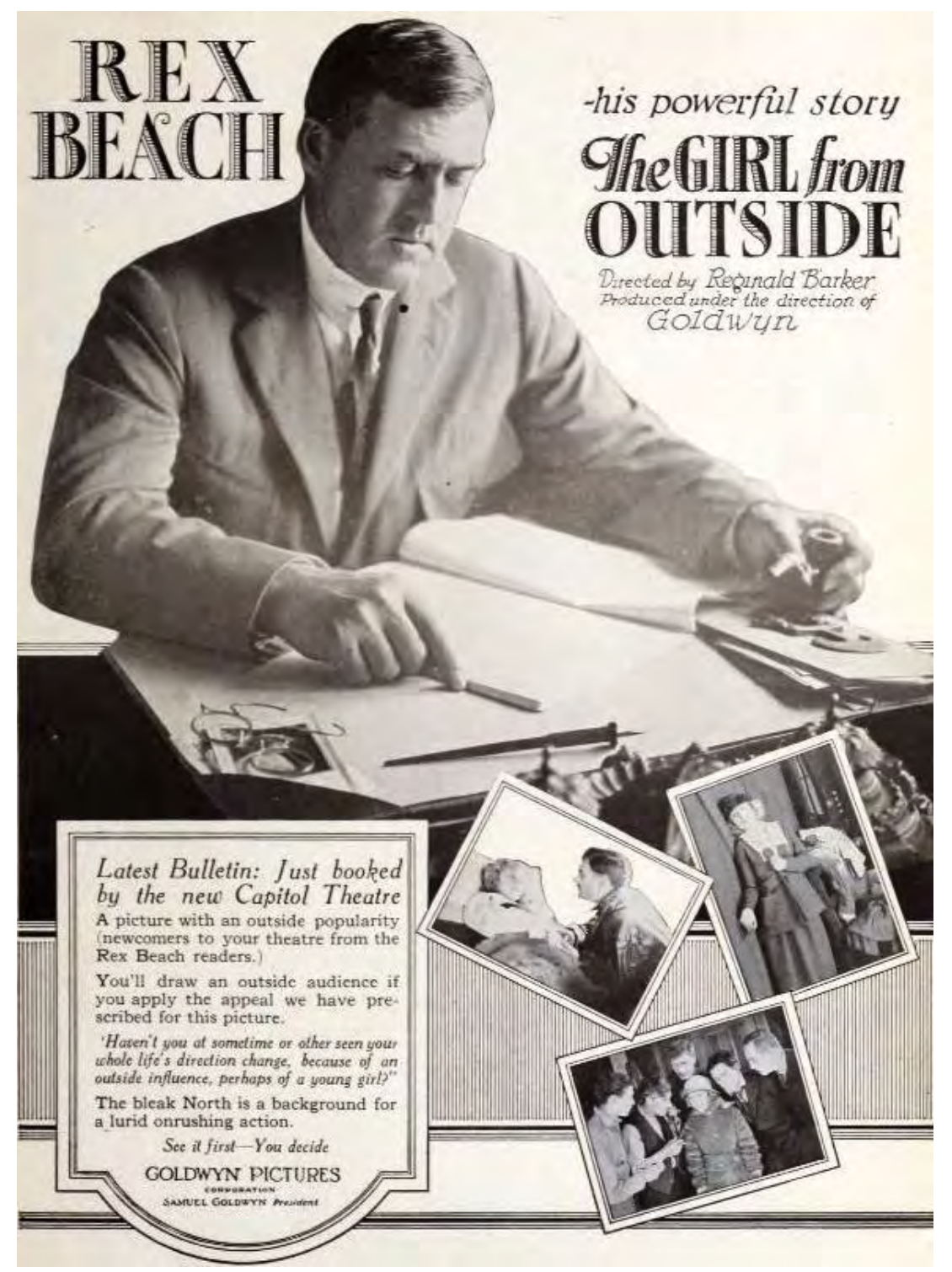

Fig. 5. Advertisement by Eminent Authors. Source: Wikimedia Commons. 


\section{Films d'auteurs contre cinéma commercial ?}

La différenciation de la valeur esthétique des films par rapport à leur popularité et à leur rentabilité est une autre dimension du processus d'autonomisation du cinéma qui a structuré les luttes de définition des auteurs du cinéma et été nourrie par ces dernières. Des scénaristes, des producteurs et des réalisateurs se sont en effet définis comme des auteurs en dénonçant les contraintes commerciales imposées par d'autres groupes professionnels (et tout particulièrement les producteurs) et en critiquant les membres de leurs professions les plus mus par l'argent ou le succès public. Pour autant, tous les prétendants au statut d'auteur n'opposaient pas la valeur esthétique des films à leur rentabilité et à leur popularité : une fraction des producteurs, des scénaristes et des réalisateurs se sont définis comme des auteurs d'un art industriel, commercial ou « populaire ». Plusieurs chercheurs ont déjà montré à raison que l'assimilation du cinéma à un " art populaire » occultait les rapports de classe structurant la production et la consommation des films (Duval 2016 ; Montebello 2003) - ce que favorise la polysémie et les usages stratégiques du mot " populaire » (Bourdieu 1983). La valorisation du cinéma en tant qu'art « populaire » n'était pas pour autant dénuée de fondements sociologiques. On rapportera les attitudes des prétendants au statut d'auteur à l'égard du succès public et de la quête de profits à des caractéristiques du marché cinématographique et aux relations entre

le cinéma et d'autres champs.

Une fraction des réalisateurs se sont définis comme des auteurs de films en dénonçant le caractère industriel du cinéma, la quête de profits et les goûts de la majorité des spectateurs. Germaine Dulac, René Clair et Maya Deren ont dénoncé les contraintes économiques imposées aux auteurs de films par les spectateurs et par d'autres prétendants au statut d'auteur (Clair 1951 : 37-43 ; Deren 1946 : 3743 ; Dulac 2004). René Clair a accusé les producteurs d'habituer

\section{Auteur Versus Commercial Cinema?}

The differentiation between the aesthetic value of films and their popularity and profitability is another dimension of the autonomization of cinema. This process has structured authorship conflicts and has been influenced by those struggles in return. Indeed, screenwriters, producers, and directors defined themselves as authors by denouncing the financial constraints imposed by other occupations (particularly producers). They also criticized the members of their own professions who were supposedly the most driven by money or public success. However, not all self-defined authors depicted aesthetic value as conflicting with profitability and popularity: some producers, screenwriters, and directors defined themselves as authors of an industrial, commercial, or "popular" art. Several scholars have perceptively pointed out that representations of cinema as a "popular art" neglected the class relations that structure the production and consumption of motion pictures (Duval 2016; Montebello 2003) - which in French is accentuated by the polysemy and strategic uses of the word populaire (Bourdieu 1983), which may mean both "widely successful" and "lowbrow." Still, the promotion of cinema as a "popular" art was not without sociological foundations. The attitudes of screenwriters, producers, and directors towards public success and the pursuit of profit should be related to characteristics of the film market and the relations between cinema and other fields.

Some directors defined themselves as film authors at odds with the industrial character of cinema, the pursuit of profit and the tastes of the majority of viewers. Germaine Dulac, René Clair, and Maya Deren denounced the economic constraints weighing on film authors owing to audiences and other workers (Clair 1951: 37-43; Deren 1946: 37-43; Dulac 2004). René Clair accused producers of accustoming audiences to poor distractions and imposing their 
le public à de mauvaises distractions et d'imposer leurs goûts aux auteurs alors qu'ils n'étaient compétents qu'en matière de commerce. Selon lui, le réalisateur pouvait néanmoins introduire, par une sorte de ruse, des fragments de " cinéma pur ", c'est-à-dire des thèmes purement visuels, dans un scénario fait pour contenter le plus grand nombre et dont la valeur littéraire était négligeable. Selon Maya Deren, les écrivains et scénaristes imposaient au cinéma des formes littéraires en contradiction avec son essence d'art visuel, tandis que les producteurs cherchaient à rentabiliser leurs énormes investissements en s'appuyant sur des matériaux, des méthodes et un personnel déjà " testés et approuvés ». Plus commune et plus tranchée du côté des réalisateurs proches de l'avant-garde, l'opposition entre la valeur cinématographique des œuvres, leur rentabilité et leur succès auprès du public n'était pas totalement absente des discours de quelques réalisateurs hollywoodiens à succès. King Vidor a salué l'attitude du producteur Irving Thalberg, pour qui la MGM pouvait se permettre quelques projets expérimentaux ne rapportant pas de profits (Vidor 1981 : 118). Il a aussi affirmé que plusieurs de ses meilleurs films avaient été des échecs au box-office et que le boxoffice ne signifiait pas grande chose à long terme (Vidor 1972 : 230).

Accusés par certains réalisateurs d'être responsables du caractère commercial du cinéma, des scénaristes et des producteurs se sont également définis comme des auteurs en dévalorisant la quête de profit ou le caractère « industriel » du cinéma. En 1945, le président du Syndicat des scénaristes français, Henri Jeanson, a opposé le cinéma comme art du scénariste à une industrie aux « marchandises bâclées » (Jeanson 1945). Il s'est aussi moqué d'autres scénaristes empochant de fortes sommes pour écrire des scénarios d'une stupidité telle que même un producteur pouvait renoncer à les tourner (Jeanson 1990 : 169-172). Des producteurs se sont également définis comme des auteurs en se distinguant d'autres membres de leurs groupes professionnels qu'ils jugeaient tastes on authors, when their only skills were in business. In his view, the director could still introduce, through some sort of ruse, fragments of "pure cinema"-meaning purely visual themes in a script with little literary value and made to please as many as possible. According to Maya Deren, writers and screenwriters forced literary forms on cinema, in contradiction to its essence as a visual art, whereas producers sought to recover their huge investments by relying on tried and true materials, methods, and personnel. More common and clear-cut among those directors closest to the avantgarde, the opposition between film value, profitability, and public success was not entirely absent in the writings of some successful Hollywood directors. King Vidor praised the attitude of producer Irving Thalberg, in whose view MGM could stand to support a few experimental projects that did not turn a profit (Vidor 1981: 118). He also claimed that several of his best films had been box-office failures and that the box-office did not mean much in the long run (Vidor 1972: 230).

Accused by some directors of being responsible for the commercial character of cinema, screenwriters and producers also defined themselves as authors by criticizing the pursuit of profit or the "industrial" dimension of cinema. In 1945, the president of the French screenwriters' union, Henri Jeanson, compared the screenwriter's art of cinema with an industry peddling "botched merchandise" (Jeanson 1945). He also took aim at other screenwriters, who pocketed large sums of money to write scripts that were so stupid that even a producer might give up on shooting them (Jeanson 1990: 169-172). Some producers also defined themselves as authors by distancing themselves from other producers, whom they accused of being too profit-driven. Raoul Ploquin, for instance, 
trop mus par l'appât du gain. Par exemple, Raoul Ploquin a opposé de bons producteurs ne sacrifiant pas la qualité du film à des fins commerciales à des " négociants " virtuoses de la combinaison financière, prêts à tout pour minimiser les coûts et maximiser les profits, au détriment de la qualité et de préoccupations artistiques et morales (Marion 1949 : 68-69). Dans ses mémoires, Pierre Braunberger a célébré son homologue états-unien Irving Thalberg au motif qu'il préférait la création de chefs-d'œuvre au strict contrôle des coûts (Braunberger \& Berger 1987 : 17-30)

Tous les prétendants au statut d'auteur ne se sont pas opposés au succès public et à la recherche de profits, loin s'en faut. En accord avec leur assimilation du cinéma à un art et une industrie, une fraction des producteurs mesuraient la valeur des films à leur profitabilité et à leur nombre de spectateurs. On peut l'observer dans les écrits de deux fondateurs de la Paramount, Jessy Lasky et Adolph Zukor. Le premier définissait le cinéma comme un art industriel. II s'est félicité d'avoir été à la tête de la société ayant obtenu le plus grand succès au monde et d'avoir produit l'un des muets les plus profitables de l'histoire, The Covered Wagon (MacCann 1987 : 143-149). Le second a intitulé son autobiographie The Public is Never Wrong (Zukor 953). Dans la même veine, le producteur français Roger Richebé a retenu comme exergue de son autobiographie cette citation de Victor Hugo : « les critiques qui affirment qu'une pièce est bonne et les critiques qui affirment qu'une pièce est mauvaise, il n'y a qu'une chose irrécusable, c'est

le fait matériel, c'est le chiffre, c'est la recette » (Richebé 1977).

Les producteurs n'étaient pas les seuls prétendants au statut d'auteur à ne pas voir de contradiction entre l'assimilation du cinéma à un art et la recherche de succès public et de profit économique. Marcel Pagnol a regretté que la critique traite le succès commercial avec mépris, « comme si la mise en exploitation d'un four n'était pas une contrasted the good producers, who did not sacrifice quality on commercial grounds, with "merchants" (Marion 1949: 68-69). The latter were supposedly virtuosos of financial arrangements, ready to do anything to bring costs down and boost their profits to the detriment of quality and artistic and moral considerations. In his memoirs, Pierre Braunberger praised his American colleague Irving Thalberg, claiming that he put creating masterpieces first and strict cost control second (Braunberger \& Berger 1987: 17-30).

Not all self-proclaimed authors were opposed to the pursuit of profit and public success-not by a long shot, in fact. As they viewed cinema as both an art and an industry, a fraction of producers measured the value of a film on the basis of its profitability and the size of its audience. This is reflected in the writings of the two Paramount founders, Jessy Lasky and Adolph Zukor. Lasky defined cinema as an industrial art (MacCann 1987: 143-149). He commended himself for being the head of the most successful company in the world and for having produced one of the most profitable silent films in history, The Covered Wagon. Zukor, for his part, entitled his autobiography The Public is Never Wrong (Zukor 1953). French producer Roger Richebé chose to use this Victor Hugo quote as an epigraph for his own memoirs: "Between the critics who claim that a play is good and the critics who claim that a play is bad, there is only one undeniable thing, and that is the material fact, the numbers, the revenue" (Richebé 1977).

Producers were not the only self-proclaimed authors who saw no contradiction in describing cinema as an art and seeking public success and economic profit. Marcel Pagnol was dismayed that critics treated commercial success with scorn, "as if the release of a flop wasn't also a commercial attempt, albeit one that didn't obtain 
tentative également commerciale, mais qui n'a pas obtenu le succès espéré » (Pagnol 1991 : 120). Tout en reprochant aux producteurs de sacrifier les intérêts des auteurs et du public à la quête de profits, un fondateur et dirigeant de la guilde des scénaristes états-uniens, Lester Cole, a avancé que le désir de produire des films de qualité et la recherche de profits n'étaient pas contradictoires (Cole 1945). Frank Capra s'est autocélébré en référence à son succès auprès du public et de « l'homme moyen », qu'il faisait primer sur les verdicts des critiques et des professionnels du cinéma (Capra 1997 : 484). S'il a dénoncé les réalisateurs animés du seul désir de gagner de l'argent, Jean Renoir a défini le cinéma comme un « art essentiellement populaire » (Renoir $1974: 78,106,296)$. II a écrit qu'il avait toujours été pénétré très honnêtement et sincèrement par le désir de plaire au public, même si son désir de classicisme le plaçait parfois en opposition avec ledit public (comme dans le cas de La Règle du jeu).

Les relations entre la valeur esthétique des films et leur popularité ont également divisé les critiques de cinéma. Dans la seconde moitié des années 1920, des critiques comme Émile Willermoz en France et John Larkin Jr. aux États-Unis ont encouragé la production de films destinés à l'élite et moins soumis aux contraintes commerciales (Abel 1988 : 274-279 ; Guzman 2005 ; Haberski 2001). En revanche, les dimensions « commerciales » ou «populaires » du cinéma ont été valorisées par d'autres critiques très réputés. Dans les années 1910 et 1920, Louis Delluc a célébré les goûts de «la foule » et considéré que le cinéma avait la chance d'être à la fois un art et une industrie, tout en encourageant les producteurs et diffuseurs à se méfier de la formule selon laquelle un bon film devait plaire à tout le monde (Abel 1985 : 15-16 ; Delluc 1985 : 186-190). En 1938, Gilbert Seldes, qui présidait le National Board of Review, a défendu un cinéma produit en faveur du plus large public possible (Hochman 1982 : 387-392) the expected success" (Pagnol 1991: 120). While he accused producers of sacrificing the interests of authors and audiences to make money, a founder and leader of the US Screen Writers Guild, Lester Cole, argued that the desire to produce quality films and the pursuit of profit were not contradictory (Cole 1945). Frank Capra celebrated his own success with the public and the "average man," whose verdicts he valued more than the opinions of critics and his Hollywood peers (Capra 1997: 484). While he denounced directors driven only by the desire to make money, Jean Renoir defined cinema as a "popular art by essence" (Renoir 1974: 78 , 106 and 296). He wrote that he had always been honestly and sincerely moved by the desire to please viewers, even if his taste for classicism sometimes put him at odds with the audience (as was the case with The Rules of the Game).

The relations between aesthetic value and the box office were also a polarizing issue for film critics. In the second half of the 1920s, critics such as Emile Willermoz in France and John Larkin Jr. in the US encouraged the production of films geared towards the elite and less dependent on commercial requirements (Abel 1988: 274-279; Guzman 2005; Haberski 2001). On the other hand, the "commercial" or "popular" dimensions of cinema were defended by other prominent critics. In the 1910s and 1920s, Louis Delluc praised the tastes of "the crowd" (Abel 1985: 15-16; Delluc 1985: 186-190). He argued that cinema was lucky to be both an art and an industry. However, Delluc also encouraged producers and cinema owners to be wary of the idea that a good film should please everybody. In 1938, Gilbert Seldes, president of the National Board of Review, said that cinema should be produced for the widest audience possible (Hochman 1982: 387-392). 
Ces visions antagonistes du succès public des films étaient des instruments de luttes entre des prétendants au statut d'auteur et des critiques de cinéma en concurrence pour la définition de la valeur des œuvres et des contributions de chaque groupe professionnel. Les attitudes différenciées des prétendants au statut d'auteur et des critiques à l'égard de la popularité des films tenaient aussi aux relations entre le champ cinématographique en voie d'autonomisation et d'autres champs plus anciens. Les prétendants au statut d'auteur étaient issus de champs où la quête de profit et de popularité était plus ou moins valorisée. On trouvait parmi eux des chefs d'entreprises non culturelles essentiellement mues par l'accumulation de capital économique et des écrivains et artistes de champs culturels plus ou moins structurés par la logique de "l'économie inversée ». La nouveauté, la popularité, les potentialités techniques et esthétiques du cinéma, ainsi que les perspectives de revenus et de reconnaissance offertes par cette activité, ont attiré des écrivains aux positions très variées dans le champ littéraire : des romanciers et dramaturges à succès, des écrivains et dramaturges consacrés ou en voie de consécration, des aspirants écrivains très peu (re)connus et des auteurs proches des avant-gardes attirés par la nouveauté de ce nouveau médium.

La valorisation ou la dévalorisation de la popularité des films tenait également aux concurrences symboliques entre les auteurs et critiques de différents champs de production culturelle. La dévalorisation du cinéma commercial peut être considérée comme un moyen de légitimer une fraction de l'offre cinématographique par rapport à des productions culturelles plus prestigieuses et structurées par la logique de l'économie inversée. On peut l'observer dans les écrits de Germaine Dulac, qui affirmait l'originalité du cinéma par rapport à tous les autres arts tout en enviant la liberté des écrivains et des peintres à l'égard des contraintes commerciales et des goûts du public (Dulac 1994). Mais la valorisation d'un cinéma «populaire »
These conflicting views on public success helped to justify the claims of self-defined authors and film critics who were promoting opposite conceptions of the value of motion pictures and the contributions of each occupation. The contrasting attitudes of authors and critics towards the popularity of films were also informed by relationships between the field of cinema-which was on a path towards autonomy-and other, older fields. Directors, screenwriters and producers came from fields where the pursuit of profit and popularity was relatively legitimate. They included heads of non-cultural companies essentially driven by the accumulation of economic capital and writers and artists from cultural fields structured to various extents by the logic of the "reversed economy." The novelty, popularity, technical, and aesthetic potentialities of cinema, as well as the opportunities for income and the recognition it offered, attracted writers with highly varied positions in the literary field: successful novelists and playwrights, consecrated or soonto-be consecrated writers and playwrights, little-known and littlerecognized aspiring writers, and avant-gardist authors attracted by the medium's novelty.

Whether the popularity of film was praised or dismissed also related to the symbolic competitions between authors and critics in various fields of cultural production. Discrediting commercial cinema could be a way to legitimate a fraction of films in relation to more prestigious cultural productions structured by the reversed economy logic. This process can be observed in the writings of Germaine Dulac, who stressed the originality of cinema compared with all the other arts, but envied writers and painters for their freedom from commercial demands and audience tastes (Dulac 1994). Yet praise for "popular" cinema could also reflect an artistic legitimation strategy - or a form of stigma reversal-in 
peut elle aussi être interprétée comme une stratégie de légitimation artistique - ou une forme de retournement du stigmate - face aux " cinéphobes » qui dévalorisaient le cinéma en tant que distraction populaire. Le critique états-unien Gilbert Seldes a valorisé les origines populaires du cinéma et son vaste public par opposition à des arts d'origine aristocratique et à des artistes et critiques s'estimant infiniment supérieurs au peuple et considérant que la valeur d'une œuvre était inversement proportionnelle à la taille de son public (Hochman 1982 : 388-390). Un autre exemple est celui de Marcel L'Herbier, qui a justifié l'abandon de ses ambitions littéraires pour une carrière cinématographique en avançant que " contrairement à la poésie iambique, l'ode filmée serait à la portée de tous et à l'échelle du monde » (L'Herbier 979 : 36-37).

Si le cinéma a pu être valorisé comme un art populaire et/ou industriel, c'est également parce qu'il n'était pas le premier à l'être ou à être valorisable en tant que tel. Jean Renoir admît que le cinéma était « peutêtre un art mineur, entaché d'industrialisme et de commercialisme ", tout en considérant qu'il en était de même d'une faïence d'Urbino, d'une tapisserie de Beauvais et même de pièces et de symphonies nécessitant elles aussi des compromissions financières (Renoir 1974 : 106). Guillaume Apollinaire a vu dans le cinéma « l'art populaire par excellence ", rappelant les temps où la poésie était « récitée par le peuple » (Duval 2016 : 133). Erwin Panosky, dont les réflexions sur le cinéma ont servi de modèle à la politique d'acquisition de la Film Library du Museum of Modern Art, a comparé la production d'un film à la construction d'une cathédrale, en rappelant que les formes d'art " non commerciales » étaient plutôt l'exception que la règle et en valorisant en tant qu'œuvres « commerciales » les gravures de Dürer et les pièces de Shakespeare (Panofsky 1936). Des références à Shakespeare ont servi à de nombreux critiques et professionnels états-uniens à valoriser le caractère « démocratique » du cinéma et à rejeter l'opposition entre l'art et le commerce (Haberski 2001 : 9-32). the face of the "cine-phobes" who dismissed cinema as a popular pastime. US critic Gilbert Seldes lauded the working-class origins of cinema and its broad audience as opposed to other arts with aristocratic roots (Hochman 1982: 388-390). He criticized artists and critics who believed that they were infinitely superior to the people and who considered that the value of a work was inversely proportional to the size of its audience. Another example is Marcel L'Herbier, who justified having given up on his literary aspirations for a career in film on the grounds that "unlike iambic poetry, the filmic ode would be accessible to all and as big as the world" (L'Herbier 1979: 36-37).

If cinema was honoured as a popular and/or industrial art, it is also because it was not the first to be honoured as such, or to warrant being so. Jean Renoir admitted that cinema "might be a minor art, sullied by industrialism and commercialism." However, the same could be said of a piece of Urbino pottery, a Beauvais tapestry, or even of plays and symphonies, which also entailed financial compromises (Renoir 1974: 106). Guillaume Apollinaire saw in cinema "the popular art par excellence," reminiscent of the times when poetry was "recited by the people" (Duval 2016: 133). Erwin Panosky, whose thoughts on cinema oriented the acquisition policy of the Museum of Modern Art's Film Library, compared the production of a motion picture to the construction of a cathedral (Panofsky 1936). He noted that "non-commercial" arts were the exception rather than the rule. Panosky also valued Dürer's engravings and Shakespeare's plays as praiseworthy "commercial" works. Many American critics and professionals made references to Shakespeare to promote the 'democratic' character of cinema and reject the conflict between art and commerce (Haberski 2001: 9-32). 
La valorisation du « cinéma populaire » a également été favorisée par la politisation de certains critiques et prétendants au statut d'auteur. Dans les années 1930, des critiques communistes, comme le Français Léon Moussinac et l'États-Unien Somerset Logan, ont dénoncé un cinéma commercial auxquels ils opposaient un art du réalisateur au service du peuple et de la Révolution (Abel 1988 : 420-421 ; Logan 1932 : 28-29)

Favorisées par les relations entre le cinéma et d'autres champs, la valorisation et la dévalorisation du succès commercial tenaient aussi à plusieurs caractéristiques de l'offre et de la demande cinématographique. La transposition au cinéma de la logique de l'économie inversée a été favorisée par de fortes inégalités de succès entre les films et par le contraste entre la reconnaissance acquise auprès d'instances de consécration et le succès commercial. Évidemment, les professionnels à succès avaient intérêt à valoriser les goûts du public et le caractère populaire du cinéma. Inversement, certains metteurs en scène d'avant-garde étaient d'autant plus susceptibles de critiquer les goûts du public que leurs films étaient peu diffusés et peu vus. Dans les années 1930, des réalisateurs français appréciés par les critiques de cinéma ont connu des échecs commerciaux ou rencontré moins de succès que des comédies oubliées par lescinéphiles (Crisp 2002:304-331). Mais des réalisateurs parmi les plus appréciés par les critiques de cinéma ont également rencontré de grands succès publics, comme Marcel L'Herbier en France et Charlie Chaplin aux États-Unis et dans le monde. Le fait que des prétendants au statut d'auteur cumulent succès public et reconnaissance critique encourageaient certains professionnels du cinéma à ne pas voir de contradiction entre la valeur esthétique des films et leur succès auprès d'un grand nombre de spectateurs. Ils y étaient d'ailleurs incités par les coûts de production des films, qui exposaient les professionnels sans succès au risque d'être exclu de l'activité cinématographique (Duval 2016). On peut également faire
The promotion of "popular cinema" was also boosted by the politicization of some critics and aspirants to author status. In the 1930s, commercial cinema was denounced by communist critics, such as the Frenchman Léon Moussinac and the American Somerset Logan. Instead, they valued an art of the director, serving the people and the Revolution (Abel 1988: 420-421; Logan 1932: 28-29).

Informed by the relations between cinema and other fields, the promotion or dismissal of commercial success also related to a number of characteristics of motion picture supply and demand. The transposition of the reversed economy logic to cinema was spurred by sharp inequalities in success between films and by the contrast between commercial success and the recognition granted by instances of consecration. Obviously, successful professionals were inclined to praise audience tastes and the popular character of cinema. Conversely, some avant-garde directors were all the more likely to criticize the tastes of the audience as their own films were seldom shown and seen. In the 1930s, French directors who are now critical favourites suffered box-office failures or had less success than directors of comedies who have since fallen into oblivion among cinephiles (Crisp 2002: 304-331). Yet some of the most critically acclaimed directors also had huge boxoffice successes, such as Marcel L'Herbier in France and Charlie Chaplin in the US and worldwide. The fact that some professionals combined public success and critical recognition encouraged some film workers not to see a contradiction between the aesthetic value of films and their commercial success. The cost of film production was also an incentive, as unsuccessful professionals risked being excluded from this activity (Duval 2016). It is also possiblethough difficult to prove-that the promotion of "popular cinema" was favoured by the ratio between cinematographic supply and demand. The first generations of upper-class cinephiles faced a 
I'hypothèse - difficile à prouver - que la valorisation d'un « cinéma populaire » était favorisée par le ratio entre l'offre et la demande cinématographique. Les premières générations de cinéphiles des classes dominantes devaient composer avec une offre plus récente, nettement plus restreinte et moins exclusive que l'offre littéraire disponible pour les écrivains, les critiques littéraires et les lecteurs les mieux dotés en capital culturel, qui pouvaient théoriquement trouver dans les rayons des bibliothèques de quoi lire tous les jours d'une vie sans toucher aux livres plaisant aux goûts « vulgaires ». La taille restreinte de l'offre cinématographique encourageait certainement les critiques à trouver ou à inventer quelques qualités à des œuvres appréciées par un public vaste et diversifié - sauf à priver de qualités un art qu'ils cherchaient justement à valoriser.

La valorisation et la dévalorisation du " cinéma commercial " tenaient aussi aux échanges et concurrences cinématographiques internationales. Le succès mondial d'une fraction de la production cinématographique française puis états-unienne a alimenté l'idée que le cinéma était un art « universel », ce que certains prétendants au statut d'auteur ont associé au fait qu'il s'adressait à toutes les classes sociales. Par exemple, aux yeux du réalisateur Jean BenoitLévy, le goût des spectateurs français pour les Marx Brothers et l'accueil enthousiaste de certains films français aux États-Unis montraient qu'« un film vraiment sincère touchera tous les publics de toutes classes, de tous les pays, et même de tous les temps " (Benoit-Lévy 1945). Mais la domination internationale du cinéma hollywoodien a également favorisé la dissociation entre la valeur esthétique des œuvres et leur succès public. Des réalisateurs français ayant travaillé aux États-Unis, comme Julien Duvivier et René Clair, ont opposé la singularité et l'individualisme du cinéma français à un « cinéma commercial » hollywoodien qu'ils jugeaient plus standardisé (Clair 1947 ; Le Forestier \& Morrissey 2011). De même, dès les années 1920 , des critiques états-uniens ont célébré l'esthétique de films européens peu diffusés dans leur pays en les opposant à des films états-uniens à succès (Guzman 2005). supply that was much more recent, limited, and less exclusive than the supply of literary works available to writers, literary critics and the readers best endowed in cultural capital. The latter could theoretically find an entire lifetime's worth of reading material in libraries without ever getting their hands on a book that might please readers with "lowbrow" tastes. The limited size of motion picture supply certainly encouraged critics to find or invent a few qualities in works that were enjoyed by a vast and diverse audience-so that they would not deny qualities to an art that they were precisely seeking to value.

The promotion and dismissal of "commercial cinema" were also related to international exchanges and competitions. The global success of a fraction of French film production, and subsequently of Hollywood films, fuelled the idea that cinema was a "universal" art-some professionals associated this with the idea that it was geared towards all social classes. For instance, to the director Jean Benoit-Lévy, the taste of French viewers for the Marx Brothers and the enthusiastic reception of some French films in the US showed that "a genuinely sincere film will affect audiences from all classes, all countries, and even all eras" (Benoit-Lévy 1945). However, the international dominance of Hollywood films also favoured the dissociation between the aesthetic value and the popularity of motion pictures. French directors who worked in Hollywood, such as Julien Duvivier and René Clair, contrasted the singularity and individualism of French cinema with what they saw as a more standardized "commercial cinema" from Hollywood (Clair 1947; Le Forestier \& Morrissey 2011). Likewise, beginning in the 1920s, American critics began celebrating the aesthetics of European films that were seldom shown in their country, in contrast to successful American films (Guzman 2005). 
Ainsi, l'assimilation du cinéma à un art populaire et la dénonciation des contraintes économiques imposées aux créateurs de films servaient différentes luttes : les luttes interprofessionnelles qui opposaient les prétendants au statut d'auteur, mais aussi les luttes intra- et transprofessionnelles qui opposaient des productions économiquement dominantes et dominées (comme le cinéma d'avant-garde au cinéma commercial ou le cinéma français au cinéma hollywoodien), les concurrences entre les professionnels et critiques du cinéma et ceux d'autres champs de production culturelle, ou encore les luttes politiques des critiques et professionnels communistes. La pluralité des luttes dans lesquelles étaient engagés les prétendants au statut d'auteur explique l'ambivalence de certains d'entre eux à l'égard du succès public. Ils pouvaient valoriser le caractère populaire du cinéma par rapport à d'autres arts tout en dénonçant les contraintes commerciales imposées par les producteurs ou la domination du marché international du cinéma par les entreprises hollywoodiennes. Par ailleurs, comme l'a remarqué Julien Duval, des réalisateurs qui entendaient toucher le plus large public possible ont pu œuvrer, par leur travail, à la création d'œuvres plus ajustées aux goûts de la fraction culturellement dominante de la classe dominante qu'à ceux des classes populaires ou d'un « grand public » transclasse (Duval $2016: 96,109$ )

\section{Conclusion}

Structurées par les relations entre le cinéma et d'autres activités, les luttes de définition des auteurs de films ont été des vecteurs d'autonomisation du champ cinématographique par rapport à d'autres champs. Importée de la littérature, du théâtre et d'autres disciplines artistiques, la notion d'auteur de film a servi à promouvoir l'autonomie du cinéma par rapport à d'autres productions culturelles et à défendre différentes visions des relations entre la valeur esthétique des films, leur rentabilité et leur popularité. Les discours
Ultimately, the depiction of cinema as a popular art and the denunciation of the economic restrictions faced by filmmakers served different struggles: the authorship between screenwriters, directors, and producers, but also the struggles between economically dominant and dominated productions (such as avantgarde versus commercial cinema and French versus Hollywood cinema), the legitimation battles that pitted film professionals and film critics against artists and critics in other cultural fields, as well as the political struggles of communist critics and professionals. The various conflicts in which "authors" were involved explained the ambivalence some of them displayed towards public success. They would emphasize the popular character of cinema in contrast to other arts while denouncing the commercial constraints imposed by producers or the domination of the international film market by Hollywood firms. Also, as Julien Duval pointed out, directors who strove to attract as broad an audience as possible may, through their work, have been influential in the creation of works that were more tailored to fit the tastes of the culturally dominant fraction of the dominant class than those of the working classes or of a crossclass audience (Duval 2016: 96 and 109).

\section{Conclusion}

Authorship conflicts were shaped by the relations between cinema and other activities. In return, they contributed to the autonomization of the field of cinema in relation to other fields. Imported from literature, theatre, and other disciplines, authorship was used to construct the autonomy of cinema from other cultural productions and to promote various visions of the relations between the aesthetic value, profitability, and popularity of motion pictures. The authorship claims of directors, producers, and screenwriters 
des prétendants au statut d'auteur montrent aussi que l'assimilation du cinéma à un art a été opérée non seulement via la différenciation de la valeur esthétique et " commerciale » des œuvres, mais aussi par la valorisation du succès auprès des spectateurs et des dimensions « populaires » du cinéma.

Tout en montrant leur indépendance, cet article encourage à ne pas confondre les processus d'autonomisation du cinéma et d'appropriation symbolique des films (et plus largement de constitution de hiérarchies professionnelles). Les réalisateurs n'ont pas été les seuls professionnels à se définir comme des auteurs de film en assimilant le cinéma à un art original. Les raisons pour lesquels ce groupe a accumulé davantage de capital symbolique que les autres prétendants au statut d'auteur dépassent le cadre de cet article, mais ne peuvent être réduites à un effet ou à un déterminant de l'autonomisation du champ cinématographique. Plus généralement, l'autonomisation du cinéma a été opérée non seulement par les groupes professionnels qui se sont attribués la valeur des films, mais aussi par tous les acteurs participant à leur fabrication, à leur diffusion et à leur valorisation. En attribuant l'essentiel de la valeur d'un film à un individu, les prises de position des prétendants au statut d'auteur ont contribué à l'invisibilisation de biens des acteurs (ou auteurs) du processus d'autonomisation du cinéma.

Jérôme Pacouret

Institut de recherche médias, cultures, communication et numérique (IRMÉCCEN)/Centre européen de sociologie et de science politique-Centre de sociologie européenne (Cessp-CSE) also show that cinema was defined as art not only through the differentiation of the aesthetic and "commercial" value of films, but also through the validation of public success and of the "popular" dimensions of cinema.

While showing that these phenomena are interdependent, this paper suggests that the autonomization of cinema and the symbolic appropriation of films (and more widely the construction of this field's professional hierarchies) are distinct processes. Directors were not the only professionals to define themselves as film authors by proclaiming the originality of cinema. The reasons why their group accumulated more symbolic capital than screenwriters and producers are beyond the scope of this paper, but they cannot be reduced to an effect or a cause of the autonomization of the field of cinema. More broadly, the autonomization of cinema was the work not only of all the occupations which claimed the authorship of motion pictures, but also of all the actors involved in their making, dissemination, and promotion. By attributing most of a film's value to a single individual, authorship claims resulted in obscuring many of the actors (or authors) of the autonomization of cinema.

Jérôme Pacouret

Institut de recherche médias, cultures, communication et numérique (IRMÉCCEN)/Centre européen de sociologie et de science politique-Centre de sociologie européenne (Cessp-CSE) 


\section{Références bibliographiques}

Aввотt Andrew (1988). The System of Professions. An Essay on the Division of Expert Labor. Chicago, University of Chicago Press.

ABEL Richard (1985). " On The Threshold of French Film Theory and Criticism, 1915-1919». Cinema Journal, 25(1) : 12-33.

Abel Richard (1988). French Film Theory and Criticism. A History/ Anthology. 1907-1939, vol. 1 et 2. Princeton, Princeton University Press.

AndReAzza Fabio (2006). « La conversion de Pirandello au cinéma ». Actes de la recherche en sciences sociales, 161-162 : 32-41.

Andreazza Fabio (2018). Canudo et le cinéma. Paris, Les Nouvelles éditions.

ARMENGOL Thérèse (2013). « La notion jurisprudentielle de droit d'auteur(s) en cinéma. La genèse : 1904-1957 ». In GAUTHIER Christophe, Vezyroglou Dimitri, Juan Myriam (dir.). L'Auteur de cinéma. Histoire généalogie, archéologie. Paris, Association française de recherche sur l'histoire du cinéma.

Baumann Shyon (2007). Hollywood Highbrow. From Entertainment to Art. Princeton, Princeton University Press.

BECKER Howard S. (1988). Les Mondes de l'art, trad. Jeanne Bouniort. Paris, Flammarion.

BENOIT-LÉVy Jean (1945). Les Grandes missions du cinéma. Montréal, L. Parizeau.

BOLTANSKI LUC (1975). «La constitution du champ de la bande dessinée ». Actes de la recherche en sciences sociales, $1: 37-59$.

\section{References}

Aввотт Andrew (1988). The System of Professions. An Essay on the Division of Expert Labor. Chicago, University of Chicago Press.

ABEL Richard (1985). "On The Threshold of French Film Theory and Criticism, 1915-1919." Cinema Journal, 25-1: 12-33.

ABEL Richard (1988). French Film Theory and Criticism. A History/ Anthology. 1907-1939, vol. 1 and 2. Princeton, Princeton University Press.

Andreazza Fabio (2006). "La conversion de Pirandello au cinéma." Actes de la recherche en sciences sociales, 161-162: 32-41.

Andreazza Fabio (2018). Canudo et le cinema. Paris, Les Nouvelles éditions.

ARMENGOL Thérèse (2013). "La notion jurisprudentielle de droit d'auteur(s) en cinéma. La genèse: 1904-1957." In GAUTHIER Christophe, VeZYROGLOU Dimitri, JuAN Myriam (eds.). L'Auteur de cinéma. Histoire, généalogie, archéologie. Paris, Association française de recherche sur l'histoire du cinéma.

Baumann Shyon (2007). Hollywood Highbrow. From Entertainment to Art. Princeton, Princeton University Press.

BECKER Howard S. (1982). Art Worlds. Berkeley, University of California Press.

Benoit-LÉvy Jean (1945). Les Grandes Missions du cinéma. Montréal, L. Parizeau.

BOLTANSKI Luc (1975). "La constitution du champ de la bande dessinée." Actes de la recherche en sciences sociales, 1: 37-59. 
BoLTANSKI Luc (1982). Les Cadres. La formation d'un groupe social. Paris, Minuit.

Bordwell David, Stalger Janet, Thompson Kristin (1985). The Classical Hollywood cinema. Film style \& mode of production to 1960. New York, Columbia University Press.

BouRdieu Pierre (1971). «Le marché des biens symboliques ». L'Année sociologique, 22 : 49-126.

BOURDIEU Pierre (1977). « La production de la croyance. Contribution à une économie des biens symboliques ". Actes de la recherche en sciences sociales, $13: 3-43$.

Bourdieu Pierre (1983). "Vous avez dit "populaire" ? ". Actes de la recherche en sciences sociales, 46 : 98-105.

BouRdieu Pierre (1984). «Espace social et genèse des "classes" ». Actes de la recherche en sciences sociales, 52-53 : 3-14.

Bourdieu Pierre (1998). Les Règles de l'art. Genèse et structure du champ littéraire. Paris, Seuil.

BouRdieu Pierre (2002). Questions de sociologie. Paris, Minuit.

Bourdieu Pierre \& Delsaut Yvette (1975). " Le couturier et sa griffe : contribution à une théorie de la magie ". Actes de la recherche en sciences sociales, $1: 7-36$.

Braunberger Pierre \& Berger Jacques (1987). Pierre Braunberger, producteur. Cinémamémoire. Paris, Éditions du Centre Pompidou/Centre national de la cinématographie.

Capra Frank (1997). The Name above the Title. An Autobiography. New York, Da Capo Press.
BOLTANSKI Luc (1982). Les Cadres. La formation d'un groupe social. Paris, Minuit.

Bordwell David, Stalger Janet, Thompson Kristin (1985). The Classical Hollywood Cinema. Film Style \& Mode of Production to 1960. New York, Columbia University Press.

BOURDIEU Pierre (1971). "Le marché des biens symboliques." L'Année sociologique, 22: 49-126.

BOURDIEU Pierre (1977). "La production de la croyance. Contribution à une économie des biens symboliques." Actes de la recherche en sciences sociales, 13: 3-43.

Bourdieu Pierre (1983). 'Vous avez dit 'populaire?' Actes de la recherche en sciences sociales, 46: 98-105.

Bourdieu Pierre (1984). "Espace social et genèse des 'classes.' Actes de la recherche en sciences sociales, 52-53: 3-14.

Bourdieu Pierre (1993). Sociology in Question. English translation by Richard Nice. London, Sage Publications.

BourdiEu Pierre (1996). The Rules of Art. Genesis and Structure of the Literary Field. English translation by Susan Emmanuel. Palo Alto, Stanford University Press.

Bourdieu Pierre \& Delsaut Yvette (1975). "Le couturier et sa griffe: contribution à une théorie de la magie." Actes de la recherche en sciences sociales, 1: 7-36.

Braunberger Pierre \& Berger Jacques (1987). Pierre Braunberger, producteur. Cinémamémoire. Paris, Éditions du Centre Pompidou/Centre national de la cinématographie. 
Carou Alain (2002). Le Cinéma français et les écrivains. Histoire d'une rencontre (1906-1914). Paris, Association française de recherche sur l'histoire du cinéma.

CAROU Alain (2011). " Le scénario français en quête d'auteurs (19081918) ». Mille huit cent quatre-vingt-quinze, 65(3) : 28-51.

CARou Alain (2013). « De l'usage de l'idée d'auteur dans l'histoire de la production cinématographique ". In GAUTHIER Christophe, VeZYROGLOU Dimitri, Juan Myriam (dir.). L'Auteur de cinéma. Histoire, généalogie, archéologie. Paris, Association française de recherche sur l'histoire du cinéma : 59-68.

Chabrol Marguerite (2016). De Broadway à Hollywood. Stratégies d'importation du théâtre new-yorkais dans le cinéma classique américain. Paris, CNRS Éditions.

Chaudron Martine \& HeINICH Nathalie (2012). « Le cinéma ». In HeINICH Nathalie \& SHAPIRO Roberta (dir.). De l'artification. Enquêtes sur le passage à l'art. Paris, Éditions de l'EHESS.

CLAIR René (1947). « Pour le cinéma français ». Le Film français, 14 mars.

CLAIR René (1951). Réflexion faite. Notes pour servir à l'histoire de l'art cinématographique de 1920 à 1950. Paris, Gallimard.

Cole Lester (1945). « Unhappy Ending ». Hollywood Quarterly, 1 : 80-84.

Copyright OfFice (1958) «Works Made for Hire and on Commission». Copyright Office of the United States, Library of Congress, avril.

CrISP Colin G. (1997). The Classic French cinema, 1930-1960. Bloomington, Londres/New York, Indiana University Press/l.B. Tauris.
CAPRA Frank (1997). The Name above the Title. An Autobiography. New York, Da Capo Press.

Carou Alain (2002). Le Cinéma français et les écrivains. Histoire d'une rencontre (1906-1914). Paris, Association française de recherche sur l'histoire du cinéma.

Carou Alain (2011). "Le scénario français en quête d'auteurs (19081918)." Mille huit cent quatre-vingt-quinze, 65(3): 28-51.

Carou Alain (2013). "De l'usage de l'idée d'auteur dans l'histoire de la production cinématographique." In Gauthier Christophe, VezYroglou Dimitri, JuAn Myriam (eds.). L'Auteur de cinéma. Histoire, généalogie, archéologie. Paris, Association française de recherche sur l'histoire du cinéma: $59-68$

CHABROL Marguerite (2016). De Broadway à Hollywood. Stratégies d'importation du théâtre new-yorkais dans le cinéma classique américain. Paris, CNRS Éditions.

Chaudron Martine \& Heinich Nathalie (2012). "Le cinéma." In HeINICH Nathalie \& SHAPIRO Roberta (eds.). De l'artification. Enquêtes sur le passage à l'art. Paris, Éditions de l'EHESS.

CLAIR René (1947). "Pour le cinéma français." Le Film français, 14 March.

CLAIR René (1951). Réflexion faite. Notes pour servir à l'histoire de l'art cinématographique de 1920 à 1950. Paris, Gallimard.

Cole Lester (1945). "Unhappy Ending." Hollywood Quarterly, 1: 80-84.

Copyright Office (1958). "Works Made for Hire and on Commission." Copyright Office of the United States, Library of Congress, April. 
Crisp Colin G. (2002). Genre, Myth, and Convention in the French Cinema, 1929-1939. Bloomington, Indiana University Press.

DeCheRney Peter (2012). Hollywood's Copyright Wars. From Edison to the Internet. New York, Columbia University Press.

DELAC Charles (1951). «Entrepreneur, chef d'orchestre ou auteur ? ». Le Film français, 26 octobre.

DeLLuC Louis (1985). Écrits cinématographiques I. Le cinéma et les cinéastes. Paris, Cinémathèque française.

Deren Maya (1946). An Anagram of Ideas on Art, Form and Film. New York, The Alicat Book Shop Press.

DUMITRU Speranta (2014). « Qu'est-ce que le nationalisme méthodologique ? Essai de typologie ». Raisons politiques, 54 : 9-22.

DULAC Germaine (1994). Écrits sur le cinéma. Paris, Paris expérimental.

Duval Julien (2016). Le Cinéma au xxe siècle. Entre loi du marché et règles de l'art. Paris, CNRS Éditions.

FINE Richard (1993). West of Eden. Writers in Hollywood, 1928-1940. Washington/Londres, Smithsonian Institution Press.

Foucault Michel (2001). «Qu'est-ce qu'un auteur ? ». In Dits et Écrits I. 1954-1975, Paris, Gallimard : 817-849.

FreY Mattias (2015). The Permanent Crisis of Film Criticism. The Anxiety of Authority. Amsterdam, Amsterdam University Press.

Gauthier Christophe (1999). La Passion du cinéma. Cinéphiles, cinéclubs et salles spécialisées à Paris de 1920 à 1929. Paris, École nationale des chartes.
CRISP Colin G. (1997). The Classic French Cinema, 1930-1960. Bloomington, London/New York, Indiana University Press/I.B. Tauris.

CRISP Colin G. (2002). Genre, Myth, and Convention in the French Cinema, 1929-1939. Bloomington, Indiana University Press.

Decherney Peter (2012). Hollywood's Copyright Wars. From Edison to the Internet. New York, Columbia University Press.

DELAC Charles (1951). "Entrepreneur, chef d'orchestre ou auteur ?" Le Film français, 26 October.

Delluc Louis (1985). Écrits cinématographiques I. Le cinéma et les cinéastes. Paris, Cinémathèque française.

Deren Maya (1946). An Anagram of Ideas on Art, Form and Film. New York, The Alicat Book Shop Press.

DUMITRU Speranta(2014). "Qu'est-ceque le nationalismeméthodologique ? Essai de typologie." Raisons politiques, 54: 9-22.

DULAC Germaine (1994). Écrits sur le cinema. Paris, Paris expérimental.

Duval Julien (2016). Le Cinéma au $x x^{e}$ siècle. Entre loi du marché et règles de l'art. Paris, CNRS Éditions.

FINE Richard (1993). West of Eden. Writers in Hollywood, 1928-1940. Washington/London, Smithsonian Institution Press.

FoucAult Michel (1969). "What is an author?" Modernity and its discontents: 299-314. [Online] [accessed on 31 January 2019].

FreY Mattias (2015). The Permanent Crisis of Film Criticism. The Anxiety of Authority. Amsterdam, Amsterdam University Press. 
GAUTHIER Christophe (2008). «L'introuvable critique. Légitimation de l'art et hybridation des discours aux sources de la critique cinématographique ». Mil neuf cent. Revue d'histoire intellectuelle, 26 : 51-72.

Gauthier Christophe, Vezyroglou Dimitri, Juan Myriam (dir.) (2013). L'Auteur de cinéma. Histoire, généalogie, archéologie. Paris, Association française de recherche sur l'histoire du cinéma.

GuZMANTony (2005). «The Little Theatre Movement :The Institutionalization of the European Art Film in America ». Film History, 17(2-3) : 261-284.

HABERSKI Raymond J. (2001). It's Only a Movie ! Films and Critics in American Culture. Lexington, University Press of Kentucky.

HeINICH Nathalie \& SHAPIRO Roberta (dir.) (2012). De l'artification. Enquêtes sur le passage à l'art. Paris, Éditions de l'EHESS.

Hochman Stanley (dir.) (1982). From Quasimodo to Scarlett O'Hara. A National Board of Review anthology, 1920-1940. New York, F. Ungar.

House of Representatives (1925) « Hearings held before the Committee on Patents, House of Representatives, Sixty-Eight Congress, Second Session, on H. R. 11258, a Bill to Amend and Consolidate the Acts Respecting Copyright and to Permit the United States to Enter the International Copyright Union ». 22 janvier.

House OF Representatives (1936). «Revision of Copyright Laws. Hearings Before the Committee on Patents. House of Representatives. SeventyFourth Congress. Second Session ».

JeAncolas Jean-Pierre, Meusy Jean-Jacques, Pinel Vincent (1996). L'Auteur du film. Description d'un combat. Lyon, SACD/Actes Sud/Institut Lumière.
GaUtHIER Christophe (1999). La Passion du cinéma. Cinéphiles, cinéclubs et salles spécialisées à Paris de 1920 à 1929. Paris, École nationale des chartes.

GAUTHIER Christophe (2008). "L'introuvable critique. Légitimation de l'art et hybridation des discours aux sources de la critique cinématographique." Mil neuf cent. Revue d'histoire intellectuelle, 26: 51-72.

Gauthier Christophe, Vezyroglou Dimitri, Juan Myriam (eds.) (2013). L'Auteur de cinéma. Histoire, généalogie, archéologie. Paris, Association française de recherche sur l'histoire du cinéma.

Guzman Tony (2005). "The little theatre movement: The institutionalization of the European art film in America." Film History, 17(2-3): 261-284.

Haberski Raymond J. (2001). It's Only a Movie! Films and Critics in American Culture. Lexington, University Press of Kentucky.

HEINICH Nathalie \& ShAPIRO Roberta (eds.) (2012). De l'artification. Enquêtes sur le passage à l'art. Paris, Éditions de l'EHESS.

Hochman Stanley (ed.) (1982). From Quasimodo to Scarlett O'Hara. A National Board of Review anthology, 1920-1940. New York, F. Ungar.

House Of Representatives (1925). "Hearings held before the Committee on Patents, House of Representatives, Sixty-Eight Congress, Second Session, on H. R. 11258, a Bill to Amend and Consolidate the Acts Respecting Copyright and to Permit the United States to Enter the International Copyright Union." 22 January.

House Of Representatives (1936). "Revision of Copyright Laws. Hearings Before the Committee on Patents. House of Representatives. SeventyFourth Congress. Second Session." 
JEANSON Henri (1945). « Lettre du syndicat des auteurs-scénaristes ». Le Film français, 37, 10 août.

JEAnson Henri (1990). 70 ans d'adolescence. Paris, Ramsay.

LA CINÉMATOGRAPHIE FRANÇAISE (1928) « Notre enquête. Qu'est-ce qu'un auteur de cinéma ? Et le droit d'auteur est-il applicable à ce nouvel Art ? ». $\mathrm{N}^{\circ} 495,28$ avril.

LE FILM FrançaIS (1951) «Réunie en assemblée générale à Venise La Fédération internationale des producteurs de films a adopté d'importantes motions ». 14 septembre.

Le Forestier Laurent \& MoRRISSEY Priska (2011). « Pour une histoire des métiers du cinéma, des origines à 1945 ». Mille huit cent quatre-vingtquinze, 65(3) : 8-27.

L'HERBIER Marcel (1979). La Tête qui tourne. Paris, Belfond.

LoGAN Somerset (1932). « Hollywood Films and the Working Class». Experimental Cinema, $4: 28-29$.

LOYANT Xavier (2009). La Société des auteurs de films (1917-1929). Thèse de master. Paris, École nationale des chartes.

MACCANN Richard Dyer (1987). The First Tycoons. Metuchen, The Scarecrow Press.

MARION Denis (dir.) (1949). Le Cinéma par ceux qui le font. Paris, Librairie Arthème Fayard.

MARY Philippe (2006). La Nouvelle Vague et le cinéma d'auteur. Socioanalyse d'une révolution artistique. Paris, Seuil.
JeAncolas Jean-Pierre, Meusy Jean-Jacques, PInEL Vincent (1996) L'Auteur du film. Description d'un combat. Lyon, SACD/Actes Sud/Institu Lumière.

JEANSON Henri (1945). "Lettre du syndicat des auteurs-scénaristes." Le Film français, 37, 10 August.

JEAnson Henri (1990). 70 ans d'adolescence. Paris, Ramsay.

La CinÉmatographie françAISE (1928). "Notre enquête. Qu'est-ce qu'un auteur de cinéma ? Et le droit d'auteur est-il applicable à ce nouvel Art ?" 495, 28 April.

LE FILM FRANÇAIS (1951). "Réunie en assemblée générale à Venise. La Fédération Internationale des Producteurs de Films a adopté d'importantes motions." 14 septembre.

Le Forestien Laurent \& MorRissey Priska (2011). "Pour une histoire des métiers du cinéma, des origines à 1945." Mille huit cent quatre-vingtquinze, 65(3): 8-27.

L'HeRBIeR Marcel (1979). La tête qui tourne. Paris, Belfond.

LOGAN Somerset (1932). "Hollywood films and the working class." Experimental Cinema, 4: 28-29.

LOYANT Xavier (2009). La Société des auteurs de films (1917-1929). Master's dissertation. Paris, l'École des chartes.

MacCann Richard Dyer (1987). The First Tycoons. Metuchen, The Scarecrow Press.

Marion Denis (ed.) (1949). Le Cinéma par ceux qui le font. Paris, Librairie Arthème Fayard. 
MaUgham Somerset (1921). «On Writing for the Films ». North American Review, $213: 670-675$

PACOURET Jérôme (2018). Qu'est-ce qu'un auteur de cinéma ? Copyright, droit d'auteur et division du travail (années 1900-2010). Thèse de doctorat en sociologie. Paris, EHESS.

Pagnol Marcel (1991). Cinématurgie de Paris. Paris, Éditions de Fallois.

PANOFSKY Erwin (1936). "Style and Medium in the Motion Pictures 》. Three essays on style. Cambridge/Londres, The MIT Press : 209.

RENOIR Jean (1974). Écrits. Paris, Ramsay.

RestoueIX Jean-Philippe (1995). « À l'origine du "sixième art". La constitution du discours sur le cinéma pensé comme art à travers les revues spécialisées avant 1914 ». In LAGNY Michèle, MARIÉ Michel, PINEL Vincent, GILI Jean-Antoine (dir.). Les Vingt Premières Années du cinéma français. Paris, Presses de la Sorbonne nouvelle/AFRHC : 311-325.

Rıchebé Roger (1977). Au-delà de l'écran. 70 ans de la vie d'un cinéaste. Monte-Carlo, Éditions Pastorelly.

Rosten Leo C. (1941). Hollywood. The Movie Colony, the Movie Makers. New York, Harcourt, Brace and Company.

SAPIRO Gisèle (2017). « Champ ». In Politika. Encyclopédie des sciences sociales du politique.

SheRman Daniel (2016). «Idées des arts et arts à idées ». In CHARLE Christophe \& JeANPIERRE Laurent (dir.). La Vie intellectuelle en France, t. II. De 1914 à nos jours. Paris, Seuil.

SHERWOOD Robert E. (1929). « Renaissance in Hollywood ». American Mercury, $16: 431-437$.
MARY Philippe (2006). La Nouvelle Vague et le cinéma d'auteur. Socioanalyse d'une révolution artistique. Paris, Seuil.

Maugham Somerset (1921). "On Writing for the Films." North American Review, 213: 670-675.

PACOURET Jérôme (2018). Qu'est-ce qu'un auteur de cinéma ? Copyright, droit d'auteur et division du travail (années 1900-2010). PhD dissertation, Sociology. Paris, EHESS.

PAGnol Marcel (1991). Cinématurgie de Paris. Paris, Éditions de Fallois.

PANOFSKY Erwin (1936). "Style and Medium in the Motion Pictures." Three essays on style. Cambridge/London, The MIT Press: 209.

RENOIR Jean (1974). Écrits. Paris, Ramsay.

RestoueIX Jean-Philippe (1995). "À l'origine du 'sixième art.' La constitution du discours sur le cinéma pensé comme art à travers les revues spécialisées avant 1914." In LAGNY Michèle, MARIÉ Michel, PINEL Vincent, GILI Jean-Antoine (eds.). Les Vingt Premières Années du cinéma français. Paris, Presses de la Sorbonne nouvelle/AFRHC: 311-325.

Richebé Roger (1977). Au-delà de l'écran. 70 ans de la vie d'un cinéaste. Monte-Carlo, Éditions Pastorelly.

Rosten Leo C. (1941). Hollywood. The Movie Colony, the Movie Makers. New York, Harcourt, Brace and Company.

SAPIRo Gisèle (2017). "Champ." In Politika. Encyclopédie des sciences sociales du politique.

ShERMAN Daniel (2016). "Idées des arts et arts à idées." In CHARLE Christophe \& JEANPIERRE Laurent (eds.). La Vie intellectuelle en France, t. 2. De 1914 à nos jours. Paris, Seuil. 
VIDOR King (1972). King Vidor on Film Making. New York, David McKay Company.

WhEATON Christopher Dudley (1974). A History of the Screen Writers' Guild (1920-1942). The Writers' Quest for a Freely Negotiated Basic Agreement. Thèse de doctorat en philosophie. Los Angeles, University of Southern California.

WimmeR Andreas \& SchILLER Glick (2002). « Methodological nationalism and beyond : nation - state building, migration and the social sciences ». Global Networks. 2(14) : 301-334

Zukor Adolph (1953). The Public is Never Wrong. New York, Putnam.
SHERWOOD Robert E. (1929). "Renaissance in Hollywood." American Mercury, 16: 431-437.

VIDOR King (1972). King Vidor on Film Making. New York, David McKay Company.

WheATON Christopher Dudley (1974). A History of the Screen Writers' Guild (1920-1942): The Writers' Quest for a Freely Negotiated Basic Agreement. PhD dissertation, Philosophy. Los Angeles, University of Southern California.

WIMMER Andreas \& SchiLleR Glick (2002). "Methodological nationalism and beyond: nation-state building, migration and the social sciences." Global Networks. 2(14): 301-334.

Zukor Adolph (1953). The Public is Never Wrong. New York, Putnam. 